\title{
Good Manufacturing Practice- Compliant Production and Lot-Release of Ex Vivo Expanded Regulatory T Cells As Basis for Treatment of Patients with Autoimmune and Inflammatory Disorders
}

OPEN ACCESS

Edited by:

Marcello Chieppa,

IRCCS de Bellis, Italy

Reviewed by:

Matthias Edinger,

Universitätsklinikum

Regensburg, Germany

Claudio Nicoletti,

University of Florence, Italy

${ }^{*}$ Correspondence:

Caroline J. Voskens caroline.bosch-voskens@ukerlangen.de

tThese authors have contributed equally to this work.

Specialty section:

This article was submitted to Mucosal Immunity,

a section of the journal

Frontiers in Immunology

Received: 21 July 2017 Accepted: 05 October 2017 Published: 26 October 2017

Citation:

Wiesinger $M$, Stoica $D$, Roessner $S$, Lorenz C, Fischer A, Atreya $R$, Neufert CF, Atreya I, Scheffold A,

Schuler-Thurner B, Neurath MF,

Schuler G and Voskens CJ (2017)

Good Manufacturing Practice-

Compliant Production and

Lot-Release of Ex Vivo Expanded

Regulatory T Cells As Basis

for Treatment of Patients

with Autoimmune and

Inflammatory Disorders.

Front. Immunol. 8:1371.

doi: 10.3389/fimmu.2017.01371
Manuel Wiesinger ${ }^{1 \dagger}$, Diane Stoica ${ }^{1 \dagger}$, Susanne Roessner ${ }^{1}$, Carmen Lorenz ${ }^{1}$, Anika Fischer ${ }^{2}$, Raja Atreya ${ }^{2}$, Clemens F. Neufert ${ }^{2}$, Imke Atreya ${ }^{2}$, Alexander Scheffold ${ }^{3}$, Beatrice Schuler-Thurner ${ }^{1}$, Markus F. Neurath ${ }^{2}$, Gerold Schuler ${ }^{1}$ and Caroline J. Voskens ${ }^{1 *}$

${ }^{1}$ Department of Dermatology, Friedrich-Alexander Universität Erlangen-Nürnberg, Erlangen, Germany, ${ }^{2}$ Department of Medicine 1, Friedrich-Alexander Universität Erlangen-Nürnberg, Erlangen, Germany, ${ }^{3}$ Department of Cellular Immunology, Clinic for Rheumatology and Clinical Immunology, Charité-University Medicine Berlin, Berlin, Germany

In recent years, the exploration of regulatory $T$ cell (Treg)-based cellular therapy has become an attractive strategy to ameliorate inflammation and autoimmunity in various clinical settings. The main obstacle to the clinical application of Treg in human is their low number circulating in peripheral blood. Therefore, ex vivo expansion is inevitable. Moreover, isolation of Treg bears the risk of concurrent isolation of unwanted effector cells, which may trigger or deteriorate inflammation upon adoptive Treg transfer. Here, we present a protocol for the GMP-compliant production, lot-release and validation of ex vivo expanded Tregs for treatment of patients with autoimmune and inflammatory disorders. In the presented production protocol, large numbers of Treg, previously enriched from a leukapheresis product by using the CliniMACS ${ }^{\circledR}$ system, are ex vivo expanded in the presence of anti-CD3/anti-CD28 expander beads, exogenous IL-2 and rapamycin during 21 days. The expanded Treg drug product passed predefined lot-release criteria. These criteria include (i) sterility testing, (ii) assessment of Treg phenotype, (iii) assessment of non-Treg cellular impurities, (iv) confirmation of successful anti-CD3/anti-CD28 expander bead removal after expansion, and (v) confirmation of the biological function of the Treg product. Furthermore, the Treg drug product was shown to retain its stability and suppressive function for at least 1 year after freezing and thawing. Also, dilution of the Treg drug product in $0.9 \%$ physiological saline did not affect Treg phenotype and Treg function for up to $90 \mathrm{~min}$. These data indicate that these cells are ready to use in a clinical setting in which a cell infusion time of up to $90 \mathrm{~min}$ can be expected. The presented production process has recently undergone on site GMP-conform evaluation and received GMP certification from the Bavarian authorities in Germany. This protocol can now be used for Treg-based therapy of various inflammatory and autoimmune disorders.

Keywords: regulatory T cell, good manufacturing practice, autoimmunity, expansion, lot-release 


\section{INTRODUCTION}

Regulatory T cells (Treg) play a critical role in maintaining immune homeostasis and limiting autoimmune responses by modulation of both innate and adaptive immunity (1). Classically defined Treg are characterized by their constitutive expression of CD4, CD25, and FoxP3 (2) and nearly absent expression of CD127 $(3,4)$. They can be divided in (i) natural Treg originating from the thymus and peripherally induced Treg, which differentiate from naïve $\mathrm{T}$ cells when self or non-self antigen is encountered under tolerogenic conditions $(5,6)$. Their existence in humans has first been described in 2001, when several groups were able to isolate (7-9) and expand (10) suppressive $\mathrm{CD} 4^{+} \mathrm{CD} 25^{+} \mathrm{T}$ cells from human peripheral blood. Animal studies have shown that Treg successfully prevent type I diabetes, experimental autoimmune encephalitis, rheumatoid arthritis, inflammatory bowel disease, systemic lupus erythematosus, scurfy disease, graft-versus-host disease, and transplant rejection (11). As a result, the exploration of Treg-based cellular therapy has become an attractive strategy to induce tolerance in various clinical settings in patients (12). However, the main obstacle to clinical application of Treg in humans is their low number circulating in peripheral blood. Therefore, initial Treg enrichment and subsequent expansion protocols are necessary to generate clinical relevant Treg numbers. Treg enrichment from a peripheral blood product is challenging, since activated conventional human $\mathrm{T}$ cells may also express CD25 (13). As a result, isolation of Treg bears the risk of concurrent isolation of unwanted effector cells.

Currently, three main strategies to isolate and expand highly enriched Treg populations from a human blood product are exploited by several research groups. First, Treg can be isolated and expanded from a donor-derived umbilical cord blood product (14-17), yet this approach is not feasible in other settings than stem cell transplantation, since it cannot be excluded that allogeneic donor-derived Treg itself induce graft-versus-host like reactions in non-transplant patients. Alternatively, highly enriched Treg populations can be isolated using good manufacturing practice (GMP)-approved flow cytometry-based (FACS) cell sorters (18-20) or the mTOR inhibitor rapamycin can be added to the cell culture process to inhibit the proliferation of contaminating effector T cells (21-23) The latter is a calcineurin inhibitor that is widely used to prevent allograft rejection after transplantation (24). Previous animal studies showed that rapamycin decreases the number of $\mathrm{CD}^{+}$cell subsets in mice, but increases the number of functional Treg (25). Based on these findings, Ogino et al. provided the proof-of-concept that mouse $\mathrm{CD}^{+} \mathrm{T}$ cells can be expanded ex vivo in the presence of rapamycin (26). The addition of rapamycin to the cell cultures affected overall expansion efficiency but effectively inhibited the outgrowth of non-suppressive effector T cells. In addition, the rapamycin-expanded Treg ameliorated colitis in an SCID mouse model.

Safinia et al. (27) were the first to establish a GMP-compliant production protocol to expand $\mathrm{CD} 25^{+}$-enriched cells from peripheral blood in the presence of rapamycin with the intention to prevent rejection after liver transplantation. In their 36-day expansion protocol, multiple rounds of in vitro Treg stimulation are necessary to reach clinically relevant Treg numbers. This may result in loss of FoxP3 expression and epigenetic stability, thus increasing the risk of in vivo Treg conversion into unwanted inflammatory effector cells.

Here, we provide the $\mathrm{CD} 25^{+}$enrichment protocol, ex vivo expansion protocol as well as the validated lot-release protocols that have been approved by the German regulatory authorities for a Treg drug product intended for clinical use in patients with autoimmune and inflammatory disorders. Treg produced by this 21-day protocol are epigenetically stable, suppressive and contain less than $0.1 \%$ of contaminating $\mathrm{CD}^{+}$effector cells. Moreover, we demonstrate the stability of the Treg drug product both after storage for up to 12 months and after subsequent dilution in a $0.9 \%$ physiological saline infusion solution. Also, we show that the Treg drug product remains polyclonal after 21 days of expansion and expresses various receptors associated with lymphocyte trafficking to secondary lymphoid organs and sites of inflammation. The protocol is scheduled to produce Treg for a phase I dose-escalation in patients and serves as an add-on platform for the adoptive transfer of Treg in a broad range of autoimmune and inflammatory disorders.

\section{MATERIAL AND METHODS}

\section{Ethical Considerations}

This study was approved by the local Institutional Review Board (IRB) of the Friedrich-Alexander-Universität Erlangen-Nürnberg under IRB number 151_12 B. In agreement with IRB approval and in accordance with the Declaration of Helsinki, oral and written consent was obtained from all healthy donors who donated blood for this study.

\section{Materials and Equipment}

The following materials are used during the Treg production process:

$\begin{array}{ll}\text { Autologous leucapherisate } & \\ \text { Autologous plasma } & \\ \text { MACS }{ }^{\circledR} \text { GMP ExpAct Treg Kit } & \text { Miltenyi Biotec (\# 170-076-119) } \\ \text { Human serum albumin } & \text { Baxter (\# PL 00116/0620) } \\ \text { MACS }{ }^{\circledR} \text { GMP Rapamycin } & \text { Miltenyi Biotec (\# 170-076-308) } \\ \text { CliniMACS }^{\circledR} \text { CD8 Reagent } & \text { Miltenyi Biotec (\# 275-01) } \\ \text { CliniMACS }^{\circledR} \text { CD19 Reagent } & \text { Miltenyi Biotec (\# 179-01) } \\ \text { CliniMACS }{ }^{\circledR} \text { CD25 Reagent } & \text { Miltenyi Biotec (\# 274-01) } \\ \text { L-Glutamine }_{\text {CliniMACS }}^{\circledR} \text { PBS/EDTA } & \text { Lonza (\# BE 17-605 E) } \\ \text { IL-2 (Proleukin }{ }^{\circledR} & \text { Miltenyi Biotec (\# 700-25) } \\ \text { X-VIVO15 } & \text { Novartis Pharma (\# PZN 02238131) } \\ \text { Dimethyl sulfoxide (DMSO) } & \text { Lonza (\# BE 04-744) } \\ \text { Glucose solution 40\% (Glucosteril 40\%) } & \text { Sigma-Aldrich (\# D2438) } \\ \end{array}$

\section{Treg Manufacture}

A detailed overview of the manufacturing process is provided in Figure 1. The complete manufacturing process is performed in the GMP facility of the department of dermatology at the Friedrich-Alexander Universität Erlangen-Nürnberg. The manufacturing process is approved by the Bavarian Authorities under number DE_BY_05_MIA_2017_0012/55.2-2678.3-41-4-16. 


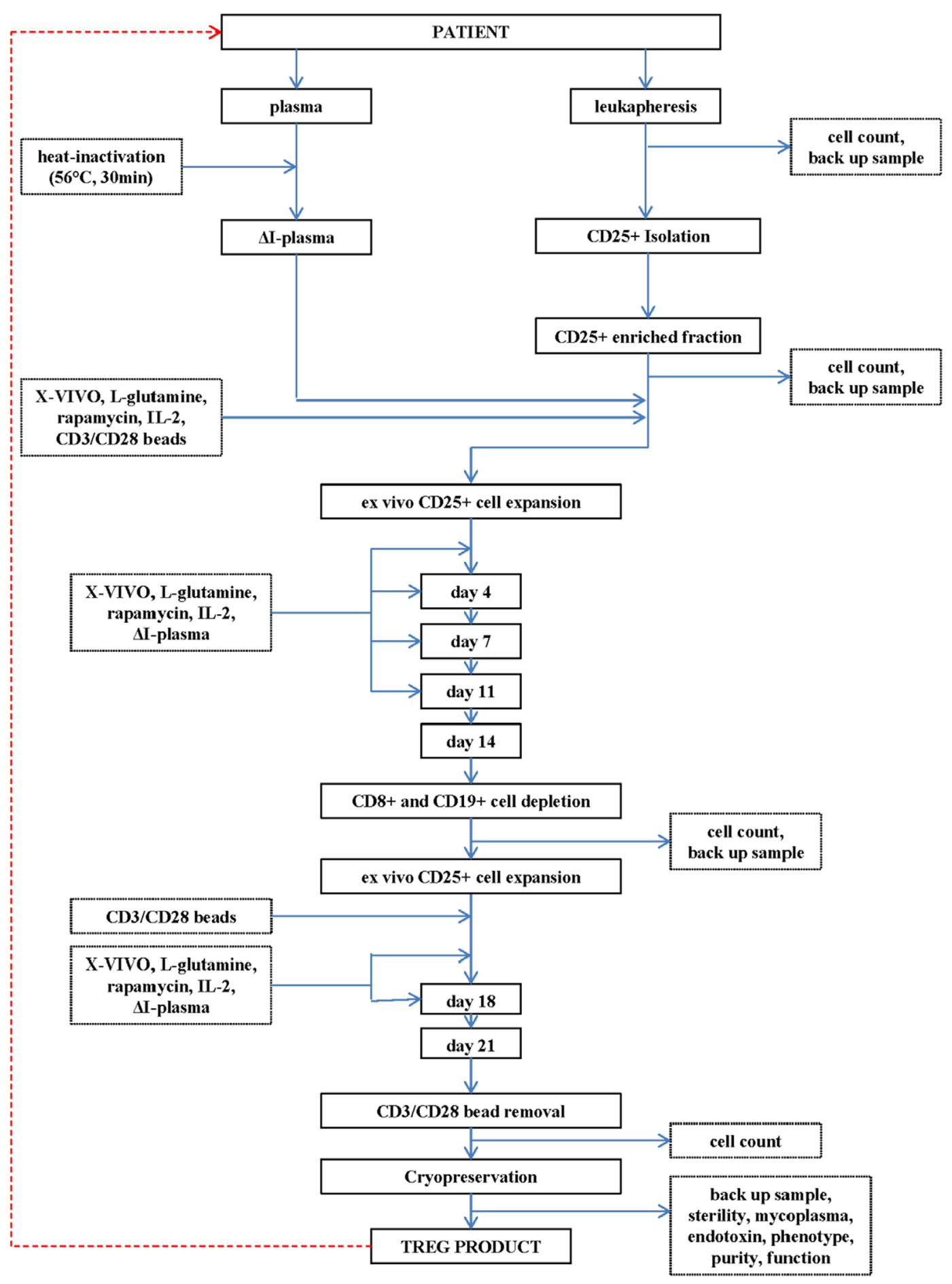

FIGURE 1 | Flowchart of the production of the regulatory T cell (Treg) drug substance and Treg drug product.

All cell purification steps are performed by using a CliniMACS ${ }^{\circledR}$ system (Miltenyi Biotec, Bergisch Gladbach, Germany) in conjunction with ISO certified CliniMACS ${ }^{\circledR}$ CD8 (Miltenyi Biotec, 275-01), CD19 (Miltenyi Biotec, 179-01), and CD25 (Miltenyi Biotec, 274-01) bead reagents. All purification steps are performed with GMP-grade CliniMACS ${ }^{\circledR}$ PBS/EDTA buffer (Miltenyi Biotec, 700-25) supplemented with clinical grade human serum albumin (Baxter, PL 00116/0620, PEI.H.03272.01-1). This buffer is hereafter called PBS-HSA-EDTA. All cell culture steps were performed in the presence of X-VIVO 15 medium without 
gentamicin and phenol red (Lonza, BE 04-744) supplemented with heat inactivated autologous plasma, clinical grade IL-2 (1,000 IU/ml, Proleukin ${ }^{\circledR}$ S, Aldesleukin, Novartis Pharma, PZN 02238131), MACS ${ }^{\circledR}$ GMP rapamycin (100 ng/ml, Miltenyi Biotec, 170-076-308), and L-glutamine (200 mM, Lonza, BE 17-605 E). This medium is hereafter called complete autologous culture medium.

A leukapheresis product (department of Transfusion Medicine, Friedrich-Alexander Universität Erlangen-Nürnberg, Erlangen, Germany) is used as cell source for initial CD $25^{+}$cell enrichment.

\section{CD25+ Cell Isolation}

The operating procedures to enrich or deplete select cell subsets from a leukapheresis product are standardized and provided by the manufacturer of the CliniMACS ${ }^{\circledR}$ device (Miltenyi Biotec). Upon arrival in the GMP facility, the leucapherisate is diluted $1+3$ with PBS-HSA-EDTA buffer and subsequently centrifuged at $200 \mathrm{~g}$ for $15 \mathrm{~min}$ at $22^{\circ} \mathrm{C}$. After centrifugation, the supernatant is removed, the leucapherisate is resuspended in PBS-HSAEDTA and centrifuged at $300 \mathrm{~g}$ for $15 \mathrm{~min}$ at $4^{\circ} \mathrm{C}$. After this centrifugation step and subsequent removal of the supernatant, the leucapherisate is resuspended in $380 \mathrm{ml}$ of cold PBS-HSA-EDTA and labeled with CliniMACS ${ }^{\circledR}$ CD25 reagent. The CliniMACS ${ }^{\circledR}$ CD25 bead reagent specifically labels up to $600 \times 10^{6} \mathrm{CD}^{2} 5^{+}$cells within a total population consisting of maximal $40 \times 10^{9}$ white blood cells. These CliniMACS ${ }^{\circledR}$ acceptance criteria are provided by Miltenyi Biotec. If one of these acceptance criteria is not met, a maximum of two portions, instead of one portion, of CliniMACS CD25 bead reagent are used to specifically label the leucapherisate. CD25-labeling is performed during $15 \pm 2 \mathrm{~min}$ at $2-8^{\circ} \mathrm{C}$ at a cell shaker programmed at $25 \mathrm{rpm}$. After labeling is completed, the cell suspension is washed with PBS-HAS-EDTA, diluted in $100 \mathrm{ml}$ PBS-HSA-EDTA and transferred into a cell collection bag. $\mathrm{CD}_{2} 5^{+}$enrichment is performed by using the automatic CliniMACS $^{\circledR}$ ENRICHMENT 3.2 program of the CliniMACS ${ }^{\circledR}$ device according to the manufacturer's instructions. The CD25+ enriched cell fraction is used for further manufacturing.

\section{Start of CD25 $5^{+}$Cell Expansion on Day 0}

Cell count and viability of the $\mathrm{CD} 25^{+}$cells was determined on two samples of $40 \mu \mathrm{l}$ by trypan blue staining according to European Pharmacopeia (Ph. Eur.) 2.7.29. Depending on cell number, $\mathrm{CD} 25^{+}$cells were seeded at a density of $0.5 \times 10^{5}$ cells $/ \mathrm{ml}$ in a 24-well or 6-well culture plate in complete autologous culture medium. To facilitate in vitro $\mathrm{CD} 25^{+}$cell expansion, clinical grade IL-2 (1,000 IU/ml), rapamycin (100 ng/ml), and anti-CD3/ anti-CD28 expander beads (MACS $^{\circledR}$ GMP ExpAct Treg Kit, Miltenyi Biotec) were added at a bead-to-cell ratio of 4:1 to the cell cultures. Cell cultures were gently mixed and incubated at $37 \pm 1^{\circ} \mathrm{C}, 5 \pm 1 \% \mathrm{CO}_{2},>70 \%$ r.h. for 4 days.

\section{Addition of Supplements at Day 4}

At day 4, fresh IL-2 (1,000 IU/ml) and rapamycin (100 ng/ml) were added to the cell cultures to substitute for cellular consumption. Cell cultures were gently mixed and incubated at $37 \pm 1^{\circ} \mathrm{C}$, $5 \pm 1 \% \mathrm{CO}_{2},>70 \%$ r.h. for 3 days.

\section{Addition of Supplements and Medium on Day 7}

At day 7, cell culture plates were collected from the incubator, and the total cell culture volume transferred into a T75 flask. Cell count and viability of the $\mathrm{CD} 25^{+}$cells was determined on two samples of $40 \mu \mathrm{l}$ by trypan blue staining according to Ph. Eur. 2.7.29. Depending on cell number, the cell density was adjusted to $0.5 \times 10^{6}$ cells $/ \mathrm{ml}$ by adding fresh complete autologous culture medium, and the cell suspension was seeded in new culture plates. To substitute for cellular consumption, fresh IL-2 (1,000 IU/ml) and rapamycin $(100 \mathrm{ng} / \mathrm{ml})$ were added. Cell cultures were gently mixed and incubated at $37 \pm 1^{\circ} \mathrm{C}, 5 \pm 1 \% \mathrm{CO}_{2},>70 \%$ r.h. for 4 days.

\section{Addition of Supplements and Medium on Day 11}

Analogous to day 7, cell culture plates were collected from the incubator, and the cell suspension, depending on the volume, transferred into a T75 or 11 cell culture flask. Cell count and viability of the CD $25^{+}$cells was determined on two samples of $40 \mu \mathrm{l}$ by trypan blue staining according to Ph. Eur. 2.7.29. Depending on cell number, the cell density was adjusted to $0.5 \times 10^{6}$ cells $/ \mathrm{ml}$ by adding fresh complete autologous culture medium. Depending on total volume, the cell suspension was seeded in T75 or T175 cell culture flasks. To substitute for cellular consumption, fresh IL-2 (1,000 IU/ml) and rapamycin (100 ng/ml) were added. Cell cultures were gently mixed and incubated at $37 \pm 1^{\circ} \mathrm{C}, 5 \pm 1 \%$ $\mathrm{CO}_{2},>70 \%$ r.h. for 3 days.

\section{Depletion of CD8 ${ }^{+}$and CD19+ Cells on Day 14}

At day 14, cell culture flasks were collected from the incubator, and the cell suspension, depending on the volume, transferred into a T75 or 11 cell culture flasks. Cell count and viability of the CD25 $5^{+}$cells was determined on two samples of $40 \mu \mathrm{l}$ by trypan blue staining according to $\mathrm{Ph}$. Eur. 2.7.29. To deplete potentially contaminating $\mathrm{CD}^{+}$and $\mathrm{CD} 19^{+}$cells, the $\mathrm{CD} 25^{+}$cell product was magnetically labeled with CliniMACS ${ }^{\circledR}$ CD8 and CliniMACS ${ }^{\circledR}$ CD19 bead reagent according to the manufactures' instructions. Specifically, up to $4 \times 10^{9} \mathrm{CD}^{+}$cells and up to $5 \times 10^{9} \mathrm{CD}^{+} 9^{+}$ cells within a total population consisting of maximal $40 \times 10^{9}$ cells may specifically be labeled by $7.5 \mathrm{ml}$ of the CliniMACS ${ }^{\circledR}$ CD8 bead reagent and CliniMACS ${ }^{\circledR}$ CD19 bead reagent, respectively. These CliniMACS ${ }^{\circledR}$ acceptance criteria were provided by Miltenyi Biotec. In general, CD25 $5^{+}$cell expansion on day 14 does not result in total cell numbers above $1 \times 10^{9}$ total cells, and the relative contamination with $\mathrm{CD}^{+}$and/or $\mathrm{CD} 19^{+}$cells is assumed to be below $25 \%$. Therefore, a predefined aliquot of $1.875 \mathrm{ml}$ of CliniMACS ${ }^{\circledR}$ CD8 bead reagent and CliniMACS ${ }^{\circledR}$ CD19 bead reagent is used to label up to $1.0 \times 10^{9} \mathrm{CD}^{+}$cells and up to $1.25 \times 10^{9} \mathrm{CD} 19^{+}$ cells within a total population consisting of maximal $10 \times 10^{9}$ cells. For depletion of $\mathrm{CD}^{+}$and $\mathrm{CD} 19^{+}$cells, sterile CliniMACS ${ }^{\circledR}$ PBS/EDTA buffer supplemented with human serum albumin is used. Depletion of $\mathrm{CD}^{+}$and $\mathrm{CD}^{+} 9^{+}$cells is performed by using the automatic CliniMACS ${ }^{\circledR}$ DEPLETION 2.1 program of the CliniMACS ${ }^{\circledR}$ device. This program facilitates automated magnetic depletion of $\mathrm{CD}^{+}$and $\mathrm{CD} 19^{+}$cells in a closed, sterile system. Two cell fractions are collected into bags according to the instrumental settings of the CliniMACS ${ }^{\circledR}$ DEPLETION 2.1 program. The $\mathrm{CD}^{+}$- and $\mathrm{CD} 19^{+}$-depleted cell fraction 2 is used for further processing. 
Cell number in fraction 2 is determined on two samples of $40 \mu \mathrm{l}$ by trypan blue staining according to Ph. Eur. 2.7.29. CD25 $5^{+}$ $\mathrm{CD}^{-} / \mathrm{CD}^{-} 9^{-}$cells of fraction 2 obtained from the CliniMACS ${ }^{\circledR}$ device are continued to be cultivated in vitro. Depending on cell number, the cell density was adjusted to $0.5 \times 10^{6}$ cells $/ \mathrm{ml}$ by adding fresh complete autologous culture medium. Depending on total volume, the cell suspension was seeded in T75 or T175 cell culture flasks. To compensate for any anti-CD3/anti-CD28 bead removal during the $\mathrm{CD} 8^{+}$and $\mathrm{CD} 19^{+}$cell depletion process, anti-CD3/anti-CD28 beads (analogously to the amount of beads used at day 0) are added to the cell cultures. Finally, fresh IL-2 $(1,000 \mathrm{IU} / \mathrm{ml})$ and rapamycin $(100 \mathrm{ng} / \mathrm{ml})$ were added. Cell cultures were gently mixed and incubated at $37 \pm 1^{\circ} \mathrm{C}, 5 \pm 1 \%$ $\mathrm{CO}_{2},>70 \%$ r.h. for 4 days.

\section{Addition of Supplements and Medium on Day 18}

Analog to days 7 and 11, cell culture plates or flasks were collected from the incubator, and the cell suspension, depending on the volume, transferred into a T75 or 11 cell culture flasks. Cell count and viability of the CD25 cells was determined on two samples of $40 \mu \mathrm{l}$ by trypan blue staining according to Ph. Eur. 2.7.29. Depending on cell number, the cell density was adjusted to $0.5 \times 10^{6}$ cells $/ \mathrm{ml}$ by adding fresh complete autologous culture medium. Depending on total volume, the cells are subsequently seeded in T75 or T175 cell culture flasks. To substitute for cellular consumption, fresh IL-2 (1,000 IU/ml) and rapamycin (100 ng/ml) are added. Cell cultures are gently mixed and incubated $\left(37 \pm 1^{\circ} \mathrm{C}, 5 \pm 1 \% \mathrm{CO}_{2},>70 \%\right.$ r.h.) for an additional 3 days.

\section{Harvesting of CD25+ Cells at Day 21}

At day 21 , cell culture plates or flasks are collected from the incubator, and the total cell culture volume is transferred into a set of $50 \mathrm{ml}$ centrifuge tubes. Culture flasks are washed once with approximately 10-20 $\mathrm{ml}$ of PBS/EDTA buffer supplemented with human serum albumin. Used washing buffer is also transferred into the $50 \mathrm{ml}$ centrifuge tubes. Tubes are centrifuged, supernatants are discarded, and pellets are collected into a set of $50 \mathrm{ml}$ centrifuge tubes by resuspending pellets with approximately $5 \mathrm{ml}$ of PBS/EDTA buffer supplemented with human serum albumin. Cell count and cell viability of $\mathrm{CD} 25^{+} / \mathrm{CD} 8^{-} \mathrm{CD} 19^{-}$cells are determined on two samples of $40 \mu \mathrm{l}$ by trypan blue staining according to Ph. Eur. 2.7.29.

\section{Anti-CD3/Anti-CD28 Expander Bead and CD25-, CD8-, and CD19-Labeling Bead Removal on Day 21}

A maximum of $2.04 \times 10^{10}$ beads can be depleted from a maximum of $4 \times 10^{10} \mathrm{CD} 25^{+}$cells in a final concentration of $20 \times 10^{6}-400 \times 10^{6} / \mathrm{ml}$ during the bead removal process. These CliniMACS $^{\circledR}$ acceptance criteria are provided by Miltenyi Biotec. In general, $\mathrm{CD} 25^{+}$cell expansion on day 21 does not result in total cell numbers above $4 \times 10^{10}$ total cells. Therefore, the assumed maximum amount of added beads is $0.48 \times 10^{10}$ [four times the maximum amount of isolated CD25+ cells at day $\left.0\left(1,200 \times 10^{6}\right)\right]$. For bead removal, sterile CliniMACS PBS/EDTA buffer supplemented with human serum albumin is used. Bead removal is performed by using the automatic CliniMACS ${ }^{\circledR}$ DEPLETION 2.1 program of the CliniMACS ${ }^{\circledR}$ device. The CliniMACS ${ }^{\circledR}$ device facilitates automated magnetic depletion of anti-CD3/anti-CD28 expander beads and CD25-, CD8-, and CD19-labeling beads in a closed, sterile system. Two cell fractions are collected into bags according to the instrumental settings of the CliniMACS ${ }^{\circledR}$ DEPLETION 2.1 program. The bead-depleted cell fraction 2 is used for filling and storage.

\section{Filling and Storage of the CD25+ Cells at Day 21}

The bead-depleted cells are transferred into a set of $50 \mathrm{ml}$ centrifuge tubes. Tubes are centrifuged, supernatants are discarded, and pellets are collected into $100 \mathrm{ml}$ of PBS/EDTA buffer supplemented with human serum albumin. The final cell number in cell fraction 2 after bead removal is determined on two samples of $40 \mu \mathrm{l}$ by trypan blue staining according to $\mathrm{Ph}$. Eur. 2.7.29. Before filling and storage, a freezing medium is freshly prepared in a sterile bottle. The total volume is calculated based on the cell counting results obtained after the first centrifugation step after the antiCD3/anti-CD28 bead removal step. The freezing medium consists of human serum albumin, DMSO, and 40\% glucose solution (hereafter called freezing medium). After definition of the final $\mathrm{CD} 25^{+}$cell number, cells are centrifuged and depending on cell number resuspended in an appropriate volume of human serum albumin at a final concentration of $20 \times 10^{6}$ viable cells $/ \mathrm{ml}$. Five hundred microliters of cell suspension are filled into each cryovial ( $1.0 \mathrm{ml}$ total volume). After addition of $500 \mu \mathrm{l}$ freezing medium (55.5 Vol.-\% human serum albumin, 25.0 Vol.-\% DMSO, and 20.0 Vol.-\% glucose) to every vial, the closed vials are mixed gently and transferred immediately into a freezing container. The container is than stored immediately at $-75 \pm 10^{\circ} \mathrm{C}$ for $4-18 \mathrm{~h}$. The vials are transferred to the gas phase of liquid nitrogen $\left(\leq-150^{\circ} \mathrm{C}\right)$ for up to 2 years.

\section{Treg Lot-Release Assessment of Treg Drug Product Identity and Cellular Composition}

Throughout the manuscript, Treg are defined as $\mathrm{CD} 4^{+} \mathrm{CD} 25^{+} \mathrm{CD} 127^{-}$cells (=Treg drug product identity) based on previously published data $(3,4)$. Treg drug product identity was determined before and after 21 days of expansion by staining with directly conjugated mouse antihuman antibodies (mAbs) against CD4 (FITC, clone RPA-T4), CD25 (FITC, clone M-A251), and CD127 (PE, clone RDR5). Treg drug product cellular composition was determined before and after 21 days of expansion by staining with directly conjugated mouse antihuman $m A b s$ against CD8 (FITC, clone SK1), CD19 (FITC, clone SJ25C1), CD16 (PE, clone 3G8), and CD56 (PE, clone B159). Corresponding $\operatorname{IgG}_{1, k}$ mouse isotype controls (FITC, clone MOPC-21 and PE, clone MOPC-21) were included to assess unspecific binding. Potential dead cells were excluded by labeling with propidium iodide (PI) (BD Biosciences) according to the manufacturer's instructions. Cells were acquired using a FACS Calibur (BD Biosciences), and data were analyzed using CellQuest ${ }^{\mathrm{TM}}$ Pro (BD Biosciences) software. For information-only purposes, cells were intracellularly stained with FoxP3 (clone PCH101) using a FoxP3/Transcription Staining Buffer Set (eBioscience, San Diego, CA, USA) according to the manufacturer's instructions. 
In general, flow cytometry is performed as described in Ph. Eur. 2.7.24. The specific method for flow cytometry was validated, since it is not in detail described in the Ph. Eur. In brief, thawed dendritic cells were used to validate the method for flow cytometry. Thawed dendritic cells, thawed lymphocytes, thawed Treg, and thawed CD25- cells were used to determine specificity. Lymphocytes were single stained with CD4, CD127, or CD8 antibody, respectively, fixed with $1 \%$ formaldehyde, washed twice and subsequently mixed with unstained lymphocytes of the same preparation. To determine specificity of the CD25 antibody, Treg were single stained with the CD25 antibody, fixed with $1 \%$ formaldehyde, washed twice and subsequently mixed with unstained Treg of the same preparation The FACS result for stained lymphocytes or Treg was set to $1(=100 \%$ positive). For specificity purposes, optimal positive and negative cells for each antibody characterizing the Treg drug product were measured. Nominal negative cells shall show less than 0.04 (=4\%) positive cells, and nominal positive cells shall show more than 0.04 (=4\%) positive ones. Summarized results are shown in Table 1. In addition, the stringent cutoff of less than $0.1 \%$ contaminating $\mathrm{CD}^{+}$cells in the final Treg product was validated separately. To avoid false negative $\mathrm{CD} 8^{+}$values in the final Treg product, the number of to acquire cells was increased to 300,000. A total of six acquisitions were performed with mature monocyte-derived dendritic cells, which represented the $\mathrm{CD}^{-}$cell subset. The SD $(s)$ was calculated from all acquired "CD8 $8^{+}$" cells within the $\mathrm{CD}^{-}$mature dendritic cell subset, and the quantification limit (QL) was calculated based on the following formula: $\mathrm{QL}=10 \mathrm{~s} / \mathrm{a}$ with $a$ set to 0.973 (=linear regression value derived from the flow cytometry validation report) (data not shown).

\section{Assessment of Treg Drug Product Purity}

Regulatory $\mathrm{T}$ cell drug product purity was determined after antiCD3/anti-CD28 expander bead removal by staining with directly conjugated mouse antihuman $\operatorname{IgG}_{3, \kappa}$ Labeling Check PE (clone AC146, Miltenyi Biotec) and APC (clone AC146, Miltenyi Biotec). Samples were acquired using a FACS Calibur (BD Biosciences), and data were analyzed using CellQuest ${ }^{\mathrm{TM}}$ Pro (BD Biosciences) software.

The method to measure anti-CD3/anti-CD28 expander bead and CD25-, CD8- and CD19-labeling bead contamination was validated since it is not described in a Ph. Eur. Specifically, thawed lymphocytes were mixed with predefined amounts of anti-CD3/ anti-CD28 expander beads and incubated for $1 \mathrm{~h}$ at $37^{\circ} \mathrm{C}$ at $5 \%$ $\mathrm{CO}_{2}$. After $1 \mathrm{~h}$ of incubation, cells were lysed using saponin $0.2 \%$ (Sigma-Aldrich, St. Louis, MI, USA) to also capture potential intracellular beads. Subsequently, beads were stained by flow cytometry with Labeling Check Reagent PE and Labeling Check Reagent APC as described above. To determine bead contamination, all samples were acquired with the use of Trucount ${ }^{\circledR}$ tubes

TABLE 1 | Validation results of analysis by flow cytometry.

\begin{tabular}{|c|c|c|c|c|c|}
\hline Validation part & Parameter & Acceptance & Result & & Passed \\
\hline \multirow[t]{3}{*}{ Reproducibility } & Coefficient of variation & $\leq 5 \%$ & 0.3 & $2.0 \%$ & $X$ yes $\square$ no \\
\hline & & & 0.5 & $2.5 \%$ & \\
\hline & & & 0.7 & $0.8 \%$ & \\
\hline \multirow[t]{6}{*}{ Intermediate precision } & Deviation of mean & $\leq 10 \%$ & 0.3 & $8.7 \%$ & $X$ yes $\square$ no \\
\hline & & & 0.5 & $4.9 \%$ & \\
\hline & & & 0.7 & $7.1 \%$ & \\
\hline & Coefficient of variation & $\leq 8 \%$ & 0.3 & $5.6 \%$ & $X$ yes $\square$ no \\
\hline & & & 0.5 & $3.8 \%$ & \\
\hline & & & 0.7 & $4.0 \%$ & \\
\hline \multirow[t]{2}{*}{ Linearity } & Correlation & $\geq 0.9$ & 1,000 & & $X$ yes $\square$ no \\
\hline & Linear regression & n.a. & $y=0.973 x+0.002$ & & $X$ yes $\square$ no \\
\hline Range & Cell fraction & $0.04-1$ & $0.04-1$ & & X yes $\square$ no \\
\hline \multirow[t]{6}{*}{ Accuracy } & Deviation from actual value & $0.3 \pm 0.03$ & 0.3 & 0.022 & $X$ yes $\square$ no \\
\hline & & $0.5 \pm 0.05$ & 0.5 & 0.019 & \\
\hline & & $0.7 \pm 0.07$ & 0.7 & 0.014 & \\
\hline & Recovery & $100 \pm 10 \%$ & 0.3 & $92.8 \%$ & $X$ yes $\square$ no \\
\hline & & & 0.5 & $96.1 \%$ & \\
\hline & & & 0.7 & $98.1 \%$ & \\
\hline Limit of detection & Quantification limit (QL) (10,000 cells) & $\leq 0.04$ & 0.016 & & $X$ yes $\square$ no \\
\hline Limit of detection CD8 & QL $(300,000$ cells) & $\leq 0.001$ & 0.001 & & $X$ yes $\square$ no \\
\hline Specificity & Fluorescence in channel 1 or 2 & Meets specificity & Meets specificity for all antibodies tested & & $X$ yes $\square$ no \\
\hline Efficiency of antibodies & Fraction of positive cells & Within range of development & All antibodies within range & & X yes $\square$ no \\
\hline
\end{tabular}

Positive cells and negative cells were mixed at the indicated fractions 0.3, 0.5, and 0.7 to represent 30, 50, and 70\% of the final cell mixture. For reproducibility, triplicate analysis of three different fractions of positive cells was statistically analyzed by coefficient of variation. The analysis of a different person on a different day was used to determine the intermediate precision. To determine linearity, 10 different fractions of positive cells were analyzed by correlation factor and linear regression. These results were compared with the theoretical real fraction contents to determine accuracy. The limits of detection were determined by analyzing six negative cell fractions and calculated with the formula: 10s/a (s indicating SD and a indicating slope of regression). Antibody specificity and efficiency were determined by using positive and negative cell fractions, respectively. 
(BD Biosciences) to assure standardized acquisition. Nominal samples negative for beads should show less than 400 beads, nominal samples positive for beads should show more than 400 beads. At least $100 \times 10^{6}$ Treg drug product cells should be lysed, labeled with Labeling Check Reagent PE and Labeling Check Reagent APC and subsequently measured to define bead contamination in the final Treg drug product. The results of the validation are summarized in Table 2 .

\section{Assessment of Treg Drug Product Function}

The method to assess Treg drug product function was validated, since it is not described in the Ph. Eur. Specifically, cryopreserved autologous $\mathrm{CD}^{-} 5^{-}$cells were thawed, washed, and labeled with $5 \mu \mathrm{M}$ carboxyfluorescein succinimidyl ester (CFSE) (ThermoFisher Scientific, Carlsbad, CA, USA). Next, CFSElabeled $\mathrm{CD}^{2} 5^{-}$cells (containing $\mathrm{CD}^{+}$and $\mathrm{CD} 8^{+}$cells; hereafter called responder cells) were cocultured with thawed day 21 Treg

TABLE 2 | Validation results of analysis of anti-CD3/anti-CD28 bead contamination.

\begin{tabular}{|c|c|c|c|c|c|}
\hline \multirow{2}{*}{$\frac{\text { Validation part }}{\text { Reproducibility }}$} & \multirow{2}{*}{$\begin{array}{l}\text { Parameter } \\
\begin{array}{l}\text { Coefficient of } \\
\text { variation }\end{array}\end{array}$} & \multirow{2}{*}{$\begin{array}{c}\text { Acceptance } \\
\leq 25\end{array}$} & \multicolumn{2}{|c|}{ Result } & \multirow{2}{*}{$\begin{array}{l}\text { Passed } \\
\text { X yes } \square \text { no }\end{array}$} \\
\hline & & & $\begin{array}{r}750 \\
1,000 \\
3,000\end{array}$ & $\begin{array}{r}7.1 \\
8.7 \\
22.7\end{array}$ & \\
\hline \multirow[t]{3}{*}{$\begin{array}{l}\text { Intermediate } \\
\text { precision }\end{array}$} & $F$-value & $<9.28$ & $\begin{array}{r}750 \\
1,000 \\
3,000\end{array}$ & $\begin{array}{l}1.54 \\
5.50 \\
2.49\end{array}$ & $\mathrm{X}$ yes $\square$ no \\
\hline & $\begin{array}{l}\text { Deviation from } \\
\text { mean }\end{array}$ & $\leq 15 \%$ & $\begin{array}{r}750 \\
1,000 \\
3,000\end{array}$ & $\begin{array}{r}6.5 \\
14.1 \\
7.3\end{array}$ & X yes $\square$ no \\
\hline & $\begin{array}{l}\text { Coefficient of } \\
\text { variation }\end{array}$ & $\leq 25$ & $\begin{array}{r}750 \\
1,000 \\
3,000\end{array}$ & $\begin{array}{l}14.0 \\
13.3 \\
17.6\end{array}$ & $\mathrm{X}$ yes $\square$ no \\
\hline Linearity & $\begin{array}{l}\text { Coefficient of } \\
\text { correlation }\end{array}$ & $\leq 0.98$ & & 96 & X yes $\square$ no \\
\hline Range & Detection range & $300-6,000$ & $300-$ & 6,000 & $\mathrm{X}$ yes $\square$ no \\
\hline \multirow[t]{2}{*}{ Accuracy } & Mean & $\begin{array}{c}637-863 \\
850-1,150 \\
2,400-3,600\end{array}$ & $\begin{array}{r}750 \\
1,000 \\
3,000\end{array}$ & $\begin{array}{c}689 \\
1,105 \\
3,420\end{array}$ & $X$ yes $\square$ no \\
\hline & Retrieval rate & $\begin{array}{l} \pm 15 \% \\
\pm 15 \% \\
\pm 20 \%\end{array}$ & $\begin{array}{r}750 \\
1,000 \\
3,000\end{array}$ & $\begin{array}{r}8.1 \% \\
10.5 \% \\
14.0 \%\end{array}$ & X yes $\square$ no \\
\hline $\begin{array}{l}\text { Limit of } \\
\text { detection }\end{array}$ & QL & $<400$ & & 90 & $\mathrm{X}$ yes $\square$ no \\
\hline \multirow[t]{2}{*}{ Specificity } & Positive particle & $>400$ & 1, & 05 & $\mathrm{X}$ yes $\square$ no \\
\hline & Negative particle & $<400$ & 3 & 8 & $X$ yes $\square$ no \\
\hline
\end{tabular}

A total of 750, 1,000, and 3,000 anti-CD3/anti-CD28 expander beads were mixed with $100 \times 10^{6}$ peripheral blood mononuclear cells. For reproducibility, triplicate analysis of indicated cell-bead mixtures was statistically analyzed by coefficient of variation. The analysis of a different person on a different day was used to determine the intermediate precision. To determine linearity, 10 different cell-bead mixtures were analyzed by correlation factor and linear regression. These results were compared with the theoretical real fraction contents to determine accuracy. The limits of detection were determined by analyzing six bead-negative cell mixtures and calculated with the formula: 10s/a (s indicating SD and a indicating slope of regression). Specificity was determined by using bead-positive and bead-negative cell mixtures, respectively. QL, quantification limit. drug product cells (hereafter called Treg) at a Treg to responder cell ratio of $1+1,1+5$, and $1+10$. Cocultures were stimulated with anti-CD3 and anti-CD28 coated beads (MACS GMP ExpAct Treg Kit, Miltenyi Biotec) at a bead-to-cell ratio of $1+1$. Negative controls included responder cells alone and Treg + responders cells at a ratio of $1+1$ without the addition of anti-CD3 and anti-CD28 coated beads. The positive control included responder cells alone with the addition of anti-CD3 and anti-CD28 coated beads at a bead + responder cell ratio of $1+4$. The absolute cell concentration and cell density at the beginning of the coculture was $1 \times 10^{6} / \mathrm{ml}$ and $1 \times 10^{6} / \mathrm{cm}^{2}$ per well, respectively.

Cocultures were routinely performed in triplicates in 48-well plates and harvested after $60-72 \mathrm{~h}$ of incubation at $37 \pm 1^{\circ} \mathrm{C}$, $5 \pm 1 \% \mathrm{CO}_{2},>70 \%$ r.h. After $60-72 \mathrm{~h}$ of incubation, conditions were harvested, stained with PI and CD8 as described under flow cytometry and acquired using a FACS Calibur (BD Biosciences). Data were analyzed using CellQuest ${ }^{\mathrm{TM}}$ Pro (BD Biosciences) software. Treg-mediated suppression was calculated based on the percentage of divided cells in the first cell generation with the positive control set to $100 \%$. One cell generation was defined to contain at least $\geq 10 \%$ divided cells. Based on all cell generations, negative control cells should show less than $5 \%$ proliferated cells, and positive control cells should show more than $30 \%$ proliferated cells. Lot-release is based on the amount of Treg-mediated suppression in cocultures with a Treg to responder cell ratio of $1+1,1+5$, and $1+10$, respectively. For validation, more Treg to responder cell ratios were included. The results of the validation are summarized in Table 3.

\section{Assessment of the Treg Drug Product Concerning Viability, Cell Number, Cell Concentration, Sterility, Bacterial Endotoxins, and Mycoplasma DNA}

Cell number, cell concentration, and cell viability are determined by trypan blue staining and microscopic examination using a hemocytometer according to the method described in Ph. Eur. 2.7.29. Sterility testing is routinely performed according to $\mathrm{Ph}$. Eur. 2.6.1 by Bioservice Scientific Laboratories (BSL) GmbH, Planegg, Germany. Testing on bacterial endotoxins is routinely performed according to Ph. Eur. 2.6.14 by BSL. Testing on mycoplasma DNA is achieved by PCR by an in-house validated method by BSL.

\section{T Cell Receptor (TCR) V $\beta$ Repertoire Analysis}

The TCR V $\beta$ repertoire of ex vivo generated CD25+ cells was determined by using the IO Test Beta Mark TCR V $\beta$ Repertoire kit (Beckman Coulter, France) as previously published (28). Day 0 derived CD25 ${ }^{+}$cells and day $21 \mathrm{CD} 25^{+}$cells were stained and analyzed for TCR V $\beta$ specificity according to the manufacturer's instructions.

\section{Epigenetic Analysis}

Genomic cellular DNA was isolated using a high pure PCR template preparation kit (Roche). Next, sodium bisulfite conversion of the purified DNA was performed by using the EpiTect ${ }^{\circledR}$ Fast DNA Bisulfite Kit (Qiagen) according to the manufacturer's 
TABLE 3 | Validation results of analysis of regulatory T cell (Treg)-mediated suppression.

\begin{tabular}{lcccl}
\hline Validation part & Sample & Specificity & Result & Passed \\
\hline Reproducibility & & & & \\
Coefficient of variation & $2+1$ & $\leq 5 \%$ & 0.3 & X yes $\square$ no \\
& $5+1$ & $\leq 5 \%$ & 1.0 & X yes $\square$ no \\
& $10+1$ & $\leq 5 \%$ & 2.2 & X yes $\square$ no \\
& $30+1$ & $\leq 5 \%$ & 4.5 & X yes $\square$ no \\
& $50+1$ & $\leq 10 \%$ & 4.9 & X yes $\square$ no \\
\hline Intermediate precision & & & & \\
Deviation from mean & $2+1$ & $\leq \pm 8 \%$ & 5.0 & X yes $\square$ no \\
& $5+1$ & $\leq \pm 12 \%$ & 7.2 & X yes $\square$ no \\
& $10+1$ & $\leq \pm 20 \%$ & 12.5 & X yes $\square$ no \\
& $30+1$ & $\leq \pm 30 \%$ & -5.6 & X yes $\square$ no \\
& $50+1$ & $\leq \pm 40 \%$ & -39.8 & X yes $\square$ no \\
\hline Coefficient of variation & $2+1$ & $\leq 10 \%$ & 2.8 & X yes $\square$ no \\
& $5+1$ & $\leq 10 \%$ & 3.8 & $X$ yes $\square$ no \\
& $10+1$ & $\leq 10 \%$ & 5.4 & $X$ yes $\square$ no \\
& $30+1$ & $\leq 15 \%$ & 4.8 & $X$ yes $\square$ no \\
& $50+1$ & $\leq 15 \%$ & 8.0 & $X$ yes $\square$ no \\
\hline
\end{tabular}

\section{Linearity}

Coefficient of correlation $100+1$ to $5+1 \quad \geq 0.8 \quad 0.908 \quad X$ yes $\square$ no in ascending range

\begin{tabular}{lcccc}
\hline Range & All samples & $\leq 10-\geq 90 \%$ & $2.4-97.7 \%$ & $X$ yes $\square$ no \\
\hline Accuracy & & & & \\
Retrieval rate & $1+1$ & $100 \pm 5 \%$ & $99.7 \%$ & $X$ yes $\square$ no \\
& $5+1$ & $100 \pm 5 \%$ & $98.4 \%$ & $X$ yes $\square$ no \\
& $10+1$ & $100 \pm 10 \%$ & $108.8 \%$ & $X$ yes $\square$ no \\
Limit of detection & & & \\
QL proliferation & & & \\
QL suppression & & $\geq 95 \%$ & $99.4 \%$ & $X$ yes $\square$ no \\
& & $X$ yes $\square$ no
\end{tabular}

Responder cells and Treg were mixed at the indicated ratios of $2+1,5+1,10+1$, $30+1$, and $50+1$. For reproducibility, triplicate analysis of responder cell to Treg ratios was statistically analyzed by coefficient of variation. The analysis of a different person on a different day was used to determine the intermediate precision. To determine linearity, 10 different responder cell to Treg ratios $(1,000+1,200+1,100+1,50+1$, $30+1,10+1,5+1,2+1,1+1$, and $1+2)$ were analyzed by correlation factor and linear regression. These results were compared with the theoretical real fraction contents to determine accuracy. The limits of detection were determined by analyzing six non-stimulated responder cell to Treg mixtures $(1+1)$ and calculated with the formula: $10 \mathrm{~s} / \mathrm{a}$ (s indicating SD and a indicating slope of regression). QL, quantification limit.

instructions. The following primers and probe enabled us to specifically detect methylated FoxP3 (29):

\section{5'-TGTCGATGAAGTTCGGCGTAT-3' (forward) \\ 5'-CCCCCGACTTACCCAAATTT-3' (reverse)}

6FAM-5' -CGGTCGTTATGACGTTAATGGCGGA-3' TAMRA (probe)

Primers and probes for the detection of unmethylated FoxP3 were designed accordingly:

5'-TGTTGATGAAGTTTGGTGTAT-3' (forward)

5'-CCCCCAACTTACCCAAATTT-3' (reverse)

6FAM-5' - TGGTTGTTATGATGTTAATGGTGGA-3' -

TAMRA (probe).

Quantitative PCR (qPCR) was performed by using the maxima probe qPCR master mix (ThermoFisher Scientific) and a C1000TM Thermal Cycler (Bio-Rad). Percentage of methylation in cells was calculated as Meth. [\%] $=100 /\left[1+2^{\Delta \mathrm{Ct} \text { (meth-unmeth) }}\right] \%$ as recently described (30). $\Delta \mathrm{Ct}$ (meth - unmeth) represents the difference between the $\mathrm{Ct}$ value of methylated FoxP3 signal and $\mathrm{Ct}$ value of unmethylated FoxP3 value. Hypomethylation was calculated as hypometh. [\%] $=100 \%-$ meth. [\%]. Since the male FoxP3 Treg-specific demethylated region (TSDR) is described to be fully demethylated, and the female TSDR shows hemimethylation (31), the above described calculation would underestimate the relative number of hypomethylated Treg in cells derived from human donors. To circumvent an underestimation, the methylation index for female-derived probes was corrected using the following formula: meth. [\%] $]_{\text {female }}=$ meth. [\%] - (100 - meth. [\%]). Similarly, hypomethylation in female derived probes was calculated as hypometh. $[\%]=100 \%-$ meth. $[\%]_{\text {female }}$.

\section{Assessment of Homing Markers}

The homing potential of day $0 \mathrm{CD} 25^{+}$cells and day 21 Treg drug product cells was assessed by staining with directly conjugated mAbs against CCR4 (clone L21H4), CCR8 (clone 191704), CD62L (clone DREG-56), CD103 (clone Ber-ATC8), CXCR3 (clone G025H7), PSGL-1 (clone 688101), CCR9 (clone L053E8), CCR5 (clone HEK/1/85a), alpha4 Integrin (clone MZ18-24A9), beta7 Integrin (clone FIB27), and the purified mAb GPR15 (clone 367902) with subsequent staining with specific mouse secondary IgG2b APC labeled antibody. Corresponding mouse isotype controls were included to assess unspecific binding. Cells were acquired using an LSR Fortessa (BD Biosciences), and data were analyzed using FlowJo software.

\section{Statistical Analysis}

Statistical differences as measured by a two-sided paired Student $t$ test were calculated using Excel v2010, based on the number of experiments as indicated in the figure legends. Differences were considered to be significant at a $P$ value less than 0.05 .

\section{RESULTS}

\section{Treg Drug Product Expansion, Viability, and Cell Number}

To validate the established GMP-complaint production protocol and the predefined lot-release criteria, we performed four subsequent Treg productions with a healthy donor-derived leukapheresis product. Such a production is also called "consistency run" (hereafter called Con) and is executed by exactly following the predefined protocol and predefined lot-release criteria. A minimum of three consecutive Cons who pass all predefined lot-release criteria is required to obtain official GMP production approval from the German authorities. With use of the protocol, leukapheresis-derived $\mathrm{CD}_{2} 5^{+}$cells expanded greater than 2 orders of magnitude with an average cell number of $113 \times 10^{6}$ at day 7 (range $34 \times 10^{6}-199 \times 10^{6}$ ), $501 \times 10^{6}$ at day 11 (range $\left.158 \times 10^{6}-849 \times 10^{6}\right), 635 \times 10^{6}$ at day $14\left(\right.$ range $234 \times 10^{6}-$ $\left.1,020 \times 10^{6}\right), 986 \times 10^{6}$ at day $18\left(\right.$ range $\left.159 \times 10^{6}-2,074 \times 10^{6}\right)$, and $1,076 \times 10^{6}\left(\right.$ range $\left.528 \times 10^{6}-1,440 \times 10^{6}\right)$ at day 21 after 
anti-CD3/anti-CD28 expander bead removal (Figures 2A,B). The exact starting Treg number and exact expansion rate per consistency run are shown in File S1 in Supplementary Material. In addition, cell viability met the predefined limit of $\geq 75 \%$ viable cells at day 7 (range 94.7-98.3\%), day 11 (range 93.5-98.7\%), day 14 (range 95.8-97.6\%), day 18 (range 94.3-98.8\%), and day 21 (range 92.9-98.3\%) after anti-CD3/anti-CD28 expander bead removal in every consistency run (Table 4).

\section{Treg Drug Product Sterility, Bacterial Endotoxins, and Mycoplasma DNA}

One thawed vial of the day 21 Treg drug product from each consistency run was tested for its sterility and the presence of bacterial toxins and mycoplasma DNA. As confirmed by BSL, no bacterial growth was contaminating the Treg drug product after 21 days of expansion. Also, no bacterial endotoxins and no mycoplasma DNA could be detected (Table 4).

\section{Treg Drug Product Identity and Cellular Composition}

The presence of CD4 ( $\geq 90.0 \%)$ and CD25 ( $\geq 80.0 \%)$ in combination with low to absent surface expression of CD127 $(\leq 10.0 \%)$ is used to phenotypically discriminate Treg from effector T cells. This approach has been elected based on studies by Liu et al. who reported that CD127 surface expression inversely correlates with FoxP3 and suppressive function of human CD4 ${ }^{+}$Treg $^{3}$. A cutoff of more than 80.0 and $90.0 \%$ was chosen for CD25 and CD4, respectively. A cutoff of less than $10.0 \%$ was chosen for CD127. Moreover, the Treg drug product cellular composition is guaranteed by the stringent cutoff criteria for potential CD8 ( $\leq 0.1 \%)$, CD19 ( $\leq 1.0 \%)$, and CD56/CD16 ( $\leq 1.0 \%)$ cells contaminating the Treg drug product. These cutoff criteria were based on the results of several clinical studies in our department with dendritic cells $(32,33)$. In these studies, a cellular contamination, based on the sum of $\mathrm{CD}^{+} \mathrm{T}$ cells, $\mathrm{CD} 19^{+} \mathrm{B}$ cells,

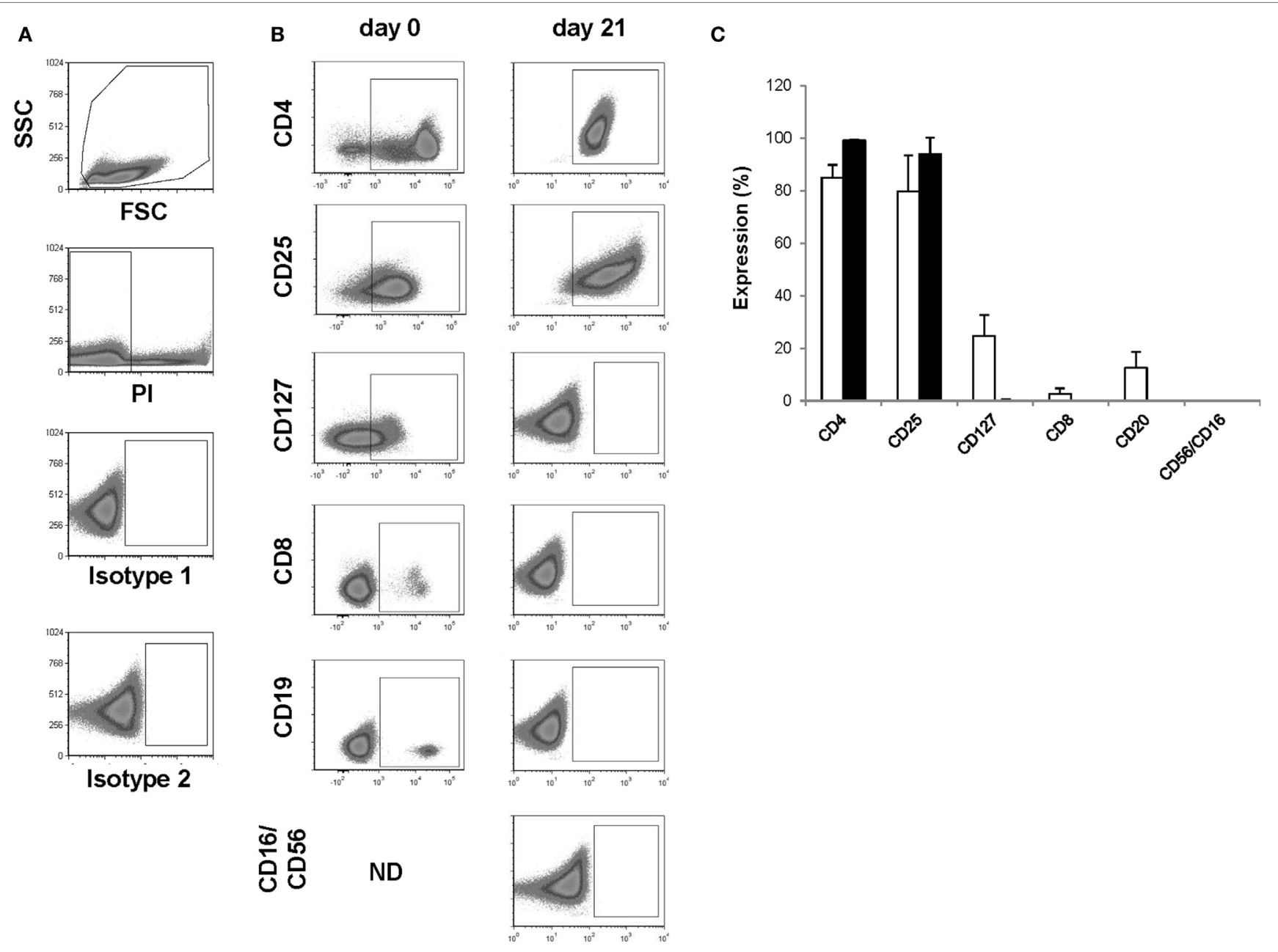

FIGURE 2 | Assessment of identity and cellular composition. (A) Representative FACS plots showing the gating strategy. (B) Representative FACS plots gated on $\mathrm{Pl}^{-}$cells showing CD4, CD25, CD127, CD8, CD19, and CD56/CD16 expression after CD25+ cell enrichment at day 0 and after thawing the day 21 regulatory T cell (Treg) drug product. (C) Proportion of Pl- cells expressing CD4, CD25, CD127, CD8, CD19, and CD56/CD16 after CD25+ cell enrichment at day $0(n=4$, white bars) and after thawing the day 21 Treg drug product ( $n=4$, filled bars). ND, not determined. 
TABLE 4 | Good manufacturing practice-compliant production process evaluation.

\begin{tabular}{|c|c|c|c|c|c|}
\hline Parameter & Limit & Con1 & Con2 & Con3 & Con4 \\
\hline Viable cells/ml & $\geq 5.0 \times 10^{6}$ & $10.5 \times 10^{6}$ & $6.3 \times 10^{6}$ & $10.8 \times 10^{6}$ & $8.2 \times 10^{6}$ \\
\hline Cell viability (\%) & $\geq 75$ & 96.7 & 92.8 & 96.8 & 96.9 \\
\hline Sterility & No growth & No growth & No growth & No growth & No growth \\
\hline Endotoxin (IU/ml) & $\leq 30$ & $\leq 30$ & $\leq 30$ & $\leq 30$ & $\leq 30$ \\
\hline Mycoplasma & Negative & Negative & Negative & Negative & Negative \\
\hline CD4 (\%) & $\geq 90.0$ & 99.6 & 99.2 & 98.6 & 99.4 \\
\hline CD25 (\%) & $\geq 80.0$ & 98.9 & 98.6 & 85.5 & 93.3 \\
\hline CD127 (\%) & $\geq 10.0$ & 0.00 & 0.05 & 0.68 & 0.00 \\
\hline CD8 (\%) & $\leq 0.10$ & 0.00 & 0.00 & 0.06 & 0.00 \\
\hline CD19 (\%) & $\leq 1.0$ & 0.00 & 0.00 & 0.00 & 0.00 \\
\hline CD56/16 (\%) & $\leq 1.0$ & 0.00 & 0.00 & 0.06 & 0.00 \\
\hline Labeling check reagent PE (\%) & $\leq 400$ & $\leq 400$ & $\leq 400$ & $\leq 400$ & $\leq 400$ \\
\hline Labeling check reagent APC (\%) & $\leq 400$ & $\leq 400$ & $\leq 400$ & $\leq 400$ & $\leq 400$ \\
\hline Suppression at ratio $1+1(\%)$ & $\geq 80.0$ & 99.5 & 81.4 & 98.2 & 99.9 \\
\hline Suppression at ratio $1+5$ (\%) & $\geq 60.0$ & 96.1 & 60.4 & 97.2 & 99.4 \\
\hline Suppression at ratio $1+10$ (\%) & $\geq 50.0$ & 85.4 & 52.5 & 61.6 & 83.2 \\
\hline
\end{tabular}

Four successive regulatory T cell (Treg) productions were performed with healthy donor-derived leukapheresis products. Productions passed the indicated limits for release. Viable cells per milliliter indicate the total number of life retrieved Treg in the final Treg product. Viability indicates the percentage of life cells in the final Treg product. Sterility indicates bacterial growth contaminating the final Treg product. CD4, CD25, CD127, CD8, CD19, and CD56/CD16 indicate surface expression on the final Treg product. Labeling check reagent PE and APC indicate the remaining number of anti-CD3/anti-CD28 beads in the final Treg product. Suppression at ratio $1+1,1+5$, and $1+10$ indicate the amount of suppression within the first generation of proliferating $C D 8^{+}$responder cells by the final Treg product.

and $\mathrm{CD} 56^{+} \mathrm{NK}$-cells, of up to $10 \%$ of the total infused cells was tolerated well by patients with cutaneous or ocular melanoma. In the case of ex vivo expanded autologous Treg, contamination with $\mathrm{CD}^{+} \mathrm{T}$ cells potentially induces inflammation in patients with autoimmune disorders. Therefore, a cutoff of less than $0.1 \%$ contaminating $\mathrm{CD}^{+}$cells was chosen for the release of the Treg drug product and a cutoff of less than $1.0 \%$ was chosen for contaminating CD19 and CD56/CD16 cells. Importantly, to reliably show less than $0.1 \% \mathrm{CD}^{+}$cell contamination in the final Treg product, a total of 300,000 cells must be acquired by flow cytometry. As shown in Figure 2 and Table 4, the performed consistency runs passed the predefined lot-release criteria for product identity and cellular composition by the validated flow cytometry method. Specifically, an average of 99.2\% CD4 (range 98.6-99.6\%), 94.1\% CD25 (range 85.5-98.9\%), 0.18\% CD127 (range $0.0-0.68 \%$ ), $0.02 \%$ CD8 (range $0.0-0.06 \%$ ), 0.0\% CD19 (range $0.0-0.0 \%$ ), and $0.2 \% \mathrm{CD} 56 / 16$ (range $0.0-0.06 \%$ ) was determined in the thawed Treg drug products. In addition, as an internal scientific in-process control, intracellular FoxP3 expression was determined on enriched day $0 \mathrm{CD}^{2} 5^{+}$cells and day 21 expanded CD25+ cells (File S2 in Supplementary Material).

\section{Treg Drug Product Purity}

The anti-CD3/anti-CD28 expander beads are removed from the cell product after 21 days of expansion using the CliniMACS ${ }^{\circledR}$ system. Although the CD25-, CD8-, and CD19-labeling beads generally are metabolized during the expansion process, potential remaining labeling beads will simultaneously be removed from the Treg drug product. As defined by our in-house validated bead removal method and shown in Figure 3 and Table 4, bead removal was efficient, since in a total of $100 \times 10^{6}$ lysed Treg product cells less than 400 beads could be retrieved by flow cytometry.

\section{Treg Drug Product Function}

Currently, the intracellular expression of FoxP3 is the most recognized marker to define Treg in human, yet intracellular FoxP3 staining mostly shows high intra-sample variation. In addition, consensus on which antibody clone to include in staining protocols is inconclusive (32-34). We, therefore, elected to omit FoxP3 expression as a separate lot-release criterion. To compensate for the lack of a highly specific Treg marker as part of our lot-release criteria, we established a biologic assay confirming the suppressive nature of the thawed Treg drug product. The objective was to reach $\geq 80.0 \%$ suppression within the first generation of divided cells at a responder cell to Treg ratio of $1+1, \geq 60.0 \%$ suppression within the first generation of divided cells at a responder cell to Treg ratio of $1+5$, and $\geq 50.0 \%$ suppression within the first generation of divided cells at a responder cell to Treg ratio of $1+10$. In addition, suppression within the first generation of divided cells at a responder cell to Treg ratio of $1+1$ had to exceed suppression within the first generation of divided cells at a responder cell to Treg ratio of $1+5$. Likewise, suppression within the first generation of divided cells at a responder cell to Treg ratio of $1+5$ had to exceed suppression within the first generation of divided cells at a responder cell to Treg ratio of $1+10$. As shown in Figure 4 and Table 4, an average responder cell proliferation of $21.3 \%$ was observed within the first generation of divided cells when no Treg were added to the coculture. In the presence of Treg at a ratio of $1+1$, responder cells showed an average of $1.09 \%$ of proliferation within the first generation of divided cells, whereas 2.37 and $6.62 \%$ of proliferation was observed at a ratio of $1+5$ and $1+10$, respectively (Figure 4C). The Treg-mediated suppression within the first generation of divided cells was calculated with the positive control set to $100 \%$, resulting in an average suppression of $94.7 \%$ at a responder cell to Treg ratio of $1+1$ (range $81.4-99.9 \%), 88.3 \%$ suppression at a responder cell to Treg ratio of $1+5$ (range $60.4-99.3 \%$ ) and $70.7 \%$ suppression 


\section{A

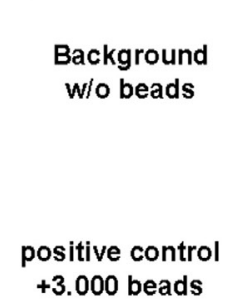

Standard
+1.000 beads

negative control +750 beads
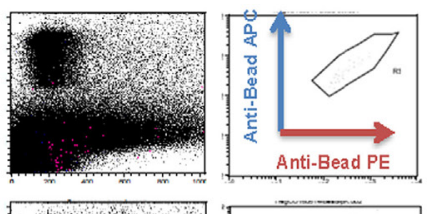

B

CON 1
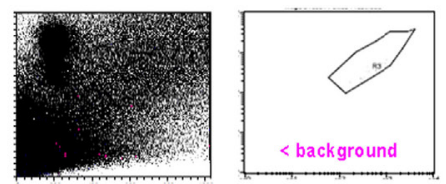

CON 2
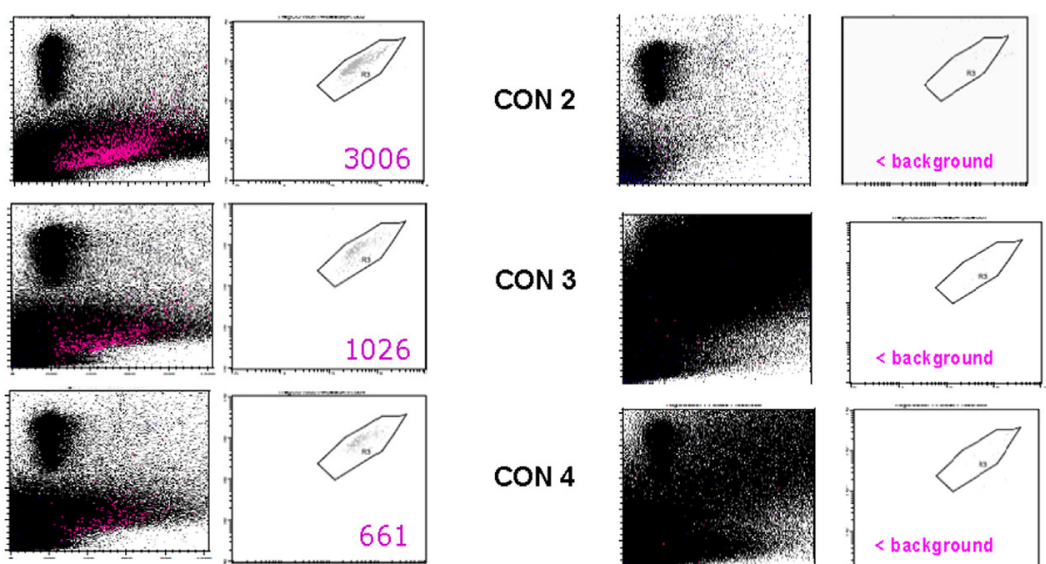

CON 3
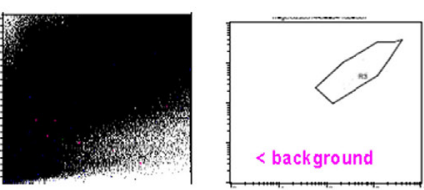

CON 4
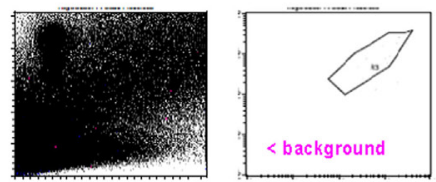

FIGURE 3 | Assessment of regulatory T cell (Treg) drug product purity. (A) Representative FACS plots gated on PE + /APC + anti-CD3/anti-CD28 expander beads in a control sample containing no anti-CD3/anti-CD28 expander beads (=background sample), a control sample containing 750 anti-CD3/anti-CD28 expander beads (=negative control sample), a control sample containing 1,000 anti-CD3/anti-CD28 expander beads (=standard sample), and a control sampler containing 3,000 anti-CD3/anti-CD28 expander beads. (B) FACS plots gated on $\mathrm{PE}^{+} / \mathrm{APC}^{+}$anti-CD3/anti-CD28 expander beads in a thawed Treg drug product from consistency run 1 (=Con1), consistency run 2 (=Con2), consistency run 3 (=Con3), and consistency run 4 (=Con4).

at a responder cell to Treg ratio of $1+10$ (range 52.5-85.5\%) (Figure 4D). In addition, average suppression within the first generation of divided cells at a responder cell to Treg ratio of $1+1$ exceeded suppression within the first generation of divided cells at a responder to Treg ratio of $1+5$. Likewise, average suppression within the first generation of divided cells at a responder cell to Treg ratio of $1+5$ exceeded suppression within the first generation of divided cells at a responder to Treg ratio of $1+10$. Moreover, based on all proliferated $\mathrm{CD}^{+}$cells, including all cell generations, a gradual increase in mean fluorescence intensity (MFI) was observed with increasing Treg to responder cell ratios with a mean MFI of 522.8 (range 440-705) at a Treg to responder cell ratio of $1+10$ and a mean MFI of 667.5 (range 539-893) at a Treg to responder cell ratio of $1+1$ (File S3A-C in Supplementary Material). Likewise, a reduction in the total number of cell generations was observed with increasing Treg to responder cell ratios (File S3D in Supplementary Material).

\section{Treg Drug Product Stability}

Stability data were acquired with Treg drug products that were continuously stored in the gas phase of liquid nitrogen $\leq-150^{\circ} \mathrm{C}$ for at least 12 months. Stored Treg drug products were thawed and analyzed according to the criteria defined for lot-release. Microbial testing, phenotyping, cellular composition, viability, recovery, and function met the limits of the drug product in every case for up to 12 months (Table 5). Therefore, guaranteed stability for the Treg drug product was set at 12 months.

Moreover, Treg drug products stored for at least 12 months from each consistency run were thawed, diluted with $0.9 \%$ sodium chloride solution and incubated for $90 \mathrm{~min}$ at $30 \pm 1{ }^{\circ} \mathrm{C}$ to mimic the preparation of the Treg drug product for adoptive transfer in clinical settings. After $90 \mathrm{~min}$ of incubation at $30 \pm 1^{\circ} \mathrm{C}$ in a $0.9 \%$ sodium chloride solution, phenotype, cellular composition, viability, recovery, and function met the preset limits of the drug product in all tested products (Table 6).

\section{Treg Drug Products Are Polyclonal, Hypomethylated, and Express Various Markers Associated with Tissue Homing}

To rule out the outgrowth of monoclonal Treg clones during the GMP-compliant production process, Treg drug products were thawed and stained with a panel of 24 distinct TCR V $\beta$ monoclonal antibodies, which cover approximately $70 \%$ of the human TCR V $\beta$ repertoire. As shown in Figure 5A, both enriched day 0 CD $25^{+}$cells and day 21 Treg expressed all 24 TCRs, indicating that the produced Treg remain polyclonal. In addition, GMPcompliant Treg production does not affect hypomethylation of the Treg at intron 1 of the FoxP3 locus, since no significant difference in hypomethylation was found between enriched day $0 \mathrm{CD} 25^{+}$ cells and day 21 Treg drug products $(P=0.5111$, Figure 5B).

Moreover, as shown in Figure 6, the Treg drug product expressed various receptors associated with lymphocyte trafficking into tissues and to sites of inflammation. Specifically, expanded Treg expressed moderate to high levels of PSGL-1, $\alpha 4 \beta 7$ integrin, CD103, CCR4, and CD62L and expression levels significantly increased during the expansion process with $P=0.0022$ for PSGL- $1, P=0.0073$ for $\alpha 4 \beta 7$ integrin, $P=0.0138$ for CD103, $P=0.0248$ for CCR4, and $P=0.0036$ for CD62L. 

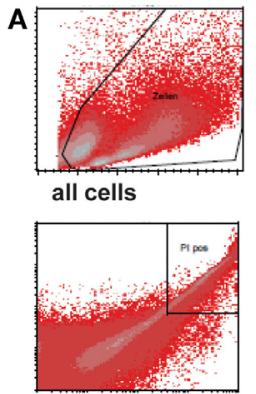

PI negativ

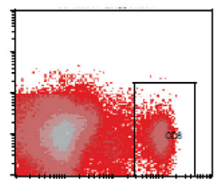

CD8 positiv
B

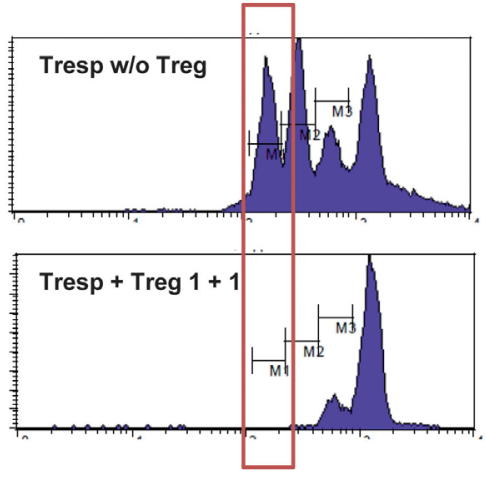

C

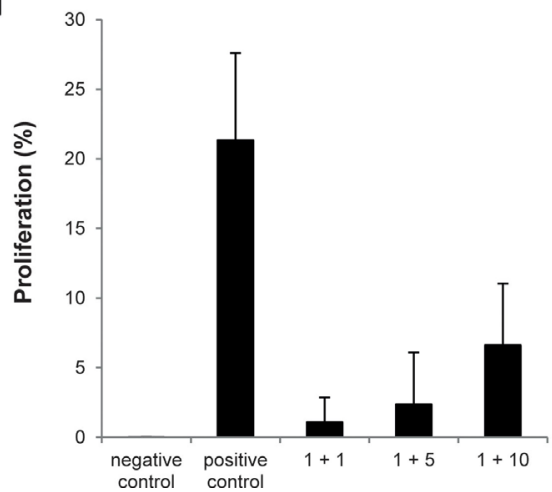

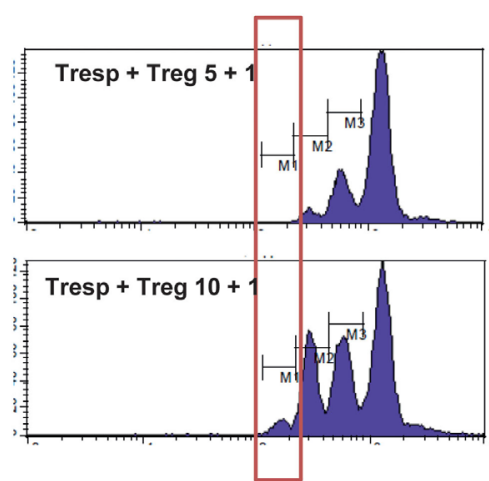

D

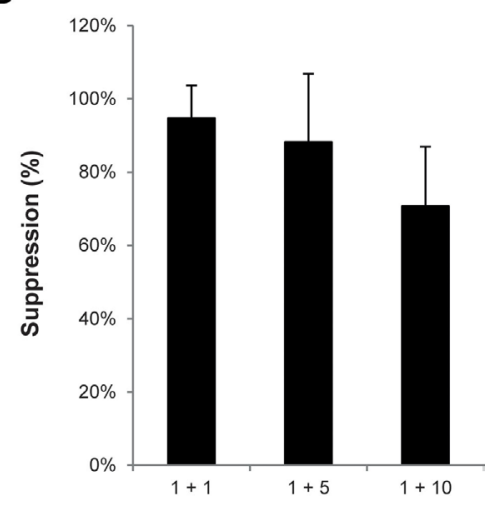

FIGURE 4 | Assessment of regulatory T cell (Treg) drug product function. (A) Representative FACS plots showing the gating strategy defining CD25- responder cell proliferation. (B) Representative histograms gated on $\mathrm{CD}^{+} / \mathrm{CFSE}^{+}$responder cells showing percentage of responder cell proliferation within the most divided cell generation in the presence of the thawed day 21 Treg drug product cells at a Treg to responder cell ratio of $1+1,1+5$, and $1+10$, respectively. (C) Proportion of the first generation of responder cells $(n=4)$ showing proliferation in the presence of no anti-CD3/anti-CD28 beads (=negative control), in the presence of anti-CD3/ anti-CD28 beads (=positive control) and at a Treg to responder cell ratio of $1+1$ (mean 1.09\%), $1+5$ (mean 2.37\%), and $1+10$ (mean $6.62 \%)$, respectively. (D) Amount of suppression in the first generation of divided cells at a Treg to responder cell ratio of $1+1$ (mean $94.7 \%), 1+5$ (mean $88.3 \%$ ), and $1+10$ (mean $70.7 \%$ ).

TABLE 5 | Results of regulatory T cell (Treg) drug product stability testing after at least 12 months of storage.

\begin{tabular}{|c|c|c|c|c|c|c|c|c|c|c|}
\hline \multirow[t]{2}{*}{ Parameter } & \multicolumn{2}{|c|}{ Con1 } & \multicolumn{2}{|c|}{ Con2 } & \multicolumn{2}{|c|}{ Con3 } & \multicolumn{2}{|c|}{ Con4 } & \multirow{2}{*}{$\begin{array}{c}\text { Acceptance } \\
\text { criteria }\end{array}$} & \multirow{2}{*}{$\begin{array}{l}\text { Criteria } \\
\text { passed }\end{array}$} \\
\hline & Release & $>12$ months & Release & $>12$ months & Release & $>12$ months & Release & $>12$ months & & \\
\hline CD4 (\%) & 99.6 & 99.7 & 99.2 & 99.2 & 98.6 & 98.7 & 99.4 & 99.3 & $\geq 90.0$ & Yes \\
\hline CD25 (\%) & 98.9 & 95.7 & 98.6 & 98.3 & 85.5 & 81.9 & 93.3 & 93.8 & $\geq 80.0$ & Yes \\
\hline CD127 (\%) & 0.0 & 1.4 & 0.1 & 2.5 & 0.7 & 1.6 & 0.0 & 1.2 & $\leq 10.0$ & Yes \\
\hline CD8 (\%) & 0.0 & 0.1 & 0.0 & 0.0 & 0.1 & 0.1 & 0.0 & 0.1 & $\leq 0.5$ & Yes \\
\hline CD19 (\%) & 0.0 & 0.0 & 0.0 & 0.0 & 0.0 & 0.0 & 0.0 & 0.0 & $\leq 1.0$ & Yes \\
\hline CD56/16 (\%) & 0.0 & 0.4 & 0.0 & 0.0 & 0.0 & 0.0 & 0.0 & 0.0 & $\leq 1.0$ & Yes \\
\hline Suppression at ratio $1+1(\%)$ & 99.5 & 95.2 & 81.4 & 99.4 & 98.2 & 96.1 & 99.9 & 98.4 & $\geq 80.0$ & Yes \\
\hline Suppression at ratio 5 + 1 (\%) & 96.1 & 80.8 & 60.4 & 85.9 & 97.2 & 66.9 & 99.4 & 79.2 & $\geq 60.0$ & Yes \\
\hline Suppression at ratio $10+1(\%)$ & 85.4 & 66.5 & 52.5 & 65.9 & 61.6 & 61.8 & 83.2 & 70.8 & $\geq 50.0$ & Yes \\
\hline viable cells $/ \mathrm{ml}\left(\times 10^{6}\right)$ & 10.5 & 9.3 & 6.3 & 9.1 & 10.8 & 9.8 & 8.2 & 7.9 & $\geq 5.0$ & Yes \\
\hline Cell viability (\%) & 96.7 & 78.7 & 92.8 & 79.7 & 96.8 & 84.1 & 96.9 & 74.1 & $\geq 50.0$ & Yes \\
\hline Sterility & ng & ng & ng & $\mathrm{ng}$ & ng & ng & ng & ng & ng & Yes \\
\hline Endotoxin (IE/ml) & $<30$ & $<30$ & $<30$ & $<30$ & $<30$ & $<30$ & $<30$ & $<30$ & $<30$ & Yes \\
\hline Mycoplasma & neg & neg & neg & neg & neg & neg & neg & neg & neg & Yes \\
\hline
\end{tabular}

Treg were thawed after a minimum of $24 \mathrm{~h}$ after production or after at least 12 months of storage at $\leq-150^{\circ} \mathrm{C}$ and analyzed for lot-release. CD4, CD25, CD127, CD8, CD19, and CD56/CD16 indicate surface expression on the final Treg product. Suppression at ratio $1+1,1+5$, and $1+10$ indicate the amount of suppression within the first generation of proliferating $\mathrm{CD}^{+}$responder cells by the final Treg product. Viable cells per milliliter indicate the total number of life retrieved Treg in the final Treg product. Viability indicates the percentage of life cells in the final Treg product. Sterility indicates bacterial growth contaminating the final Treg product.

ng, no growth; neg, negative. 
TABLE 6 | Results of regulatory T cell (Treg) drug product stability testing in the clinical application solution.

\begin{tabular}{|c|c|c|c|c|c|c|c|c|c|c|}
\hline \multirow[t]{2}{*}{ Parameter } & \multicolumn{2}{|c|}{ Con1 } & \multicolumn{2}{|c|}{ Con2 } & \multicolumn{2}{|c|}{ Con3 } & \multicolumn{2}{|c|}{ Con4 } & \multirow{2}{*}{$\begin{array}{c}\text { Acceptance } \\
\text { criteria }\end{array}$} & \multirow[t]{2}{*}{ Criteria passed } \\
\hline & $0.5 \times 10^{6} / \mathrm{ml}$ & $20 \times 10^{6} / \mathrm{ml}$ & $0.5 \times 10^{6} / \mathrm{ml}$ & $20 \times 10^{6} / \mathrm{ml}$ & $0.5 \times 10^{6} / \mathrm{ml}$ & $20 \times 10^{6} / \mathrm{ml}$ & $0.5 \times 10^{6} / \mathrm{ml}$ & $20 \times 10^{6} / \mathrm{ml}$ & & \\
\hline CD4 (\%) & 93.2 & 98.9 & 97.3 & 98.2 & 98.7 & 98.4 & 99.5 & 99.4 & $\geq 90.0$ & Yes \\
\hline CD25 (\%) & 89.1 & 87.5 & 86.1 & 96.6 & 81.1 & 86.0 & 95.9 & 94.6 & $\geq 80.0$ & Yes \\
\hline CD127 (\%) & 0.2 & 0.1 & 0.9 & 0.0 & 6.8 & 4.8 & 3.3 & 1.9 & $\leq 10.0$ & Yes \\
\hline CD8 (\%) & 0.0 & 0.1 & 0.0 & 0.0 & 0.1 & 0.1 & 0.0 & 0.1 & $\leq 0.5$ & Yes \\
\hline CD19 (\%) & 0.0 & 0.0 & 0.0 & 0.0 & 0.0 & 0.0 & 0.0 & 0.0 & $\leq 1.0$ & Yes \\
\hline CD56/16 (\%) & 0.0 & 0.4 & 0.0 & 0.0 & 0.0 & 0.0 & 0.0 & 0.0 & $\leq 1.0$ & Yes \\
\hline Suppression at ratio $1+1(\%)$ & 97.7 & 96.5 & 98.8 & 97.6 & 97.0 & 96.5 & 93.5 & 96.6 & $\geq 80.0$ & Yes \\
\hline Suppression at ratio 5 + 1 (\%) & 90.3 & 91.7 & 94.7 & 96.2 & 91.7 & 76.1 & 82.5 & 92.6 & $\geq 60.0$ & Yes \\
\hline Suppression at ratio $10+1(\%)$ & 81.6 & 87.1 & 70.3 & 70.3 & 78.5 & 63.6 & 56.9 & 55.2 & $\geq 50.0$ & Yes \\
\hline Viable cells/ml $\left(\times 10^{6}\right)$ & 7.3 & 6.7 & 6.1 & 5.7 & 6.0 & 5.5 & 7.1 & 5.7 & $\geq 5.0$ & Yes \\
\hline Viability (\%) & 76.1 & 70.5 & 78.0 & 70.6 & 77.2 & 79.1 & 74.9 & 76.3 & $\geq 50.0$ & Yes \\
\hline
\end{tabular}

Treg were thawed at least 12 months after storage at $\leq-150^{\circ} \mathrm{C}$ and analyzed for stability in a $0.9 \%$ sodium chloride solution at indicated Treg concentrations. CD4, CD25, CD127, CD8, CD19, and CD56/CD16 indicate surface expression on the final Treg product. Suppression at ratio 1+1, 1+5, and 1+10 indicate the amount of suppression within the first generation of proliferating CD8+ responder cells by the final Treg product. Viable cells per milliliter indicate the total number of life retrieved Treg in the final Treg product. Viability indicates the percentage of life cells in the final Treg product.

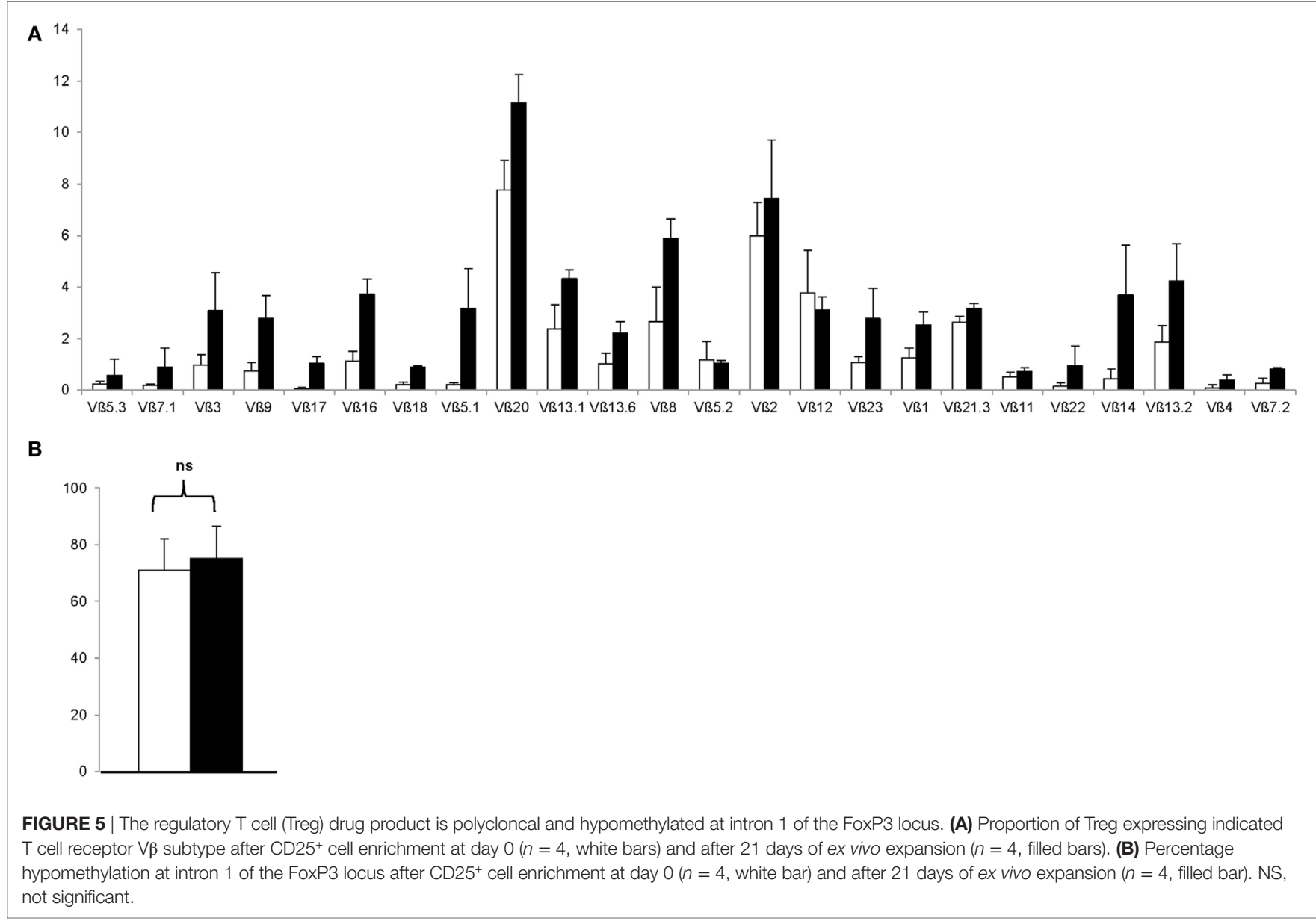

Also, high levels of CCR5 and CXCR3 were expressed on both day $0 \mathrm{CD} 25^{+}$enriched cells and day 21 Treg, whereas only little to moderate expression levels of CCR8, CCR9, and GPR15 were detected.
Risk Management and Limits of Detection

A major risk in the presented protocol is the detection of human immunodeficiency virus (HIV), hepatitis B virus (HBV), or hepatitis $\mathrm{C}$ virus $(\mathrm{HCV})$ antigens or microbiological impurities 

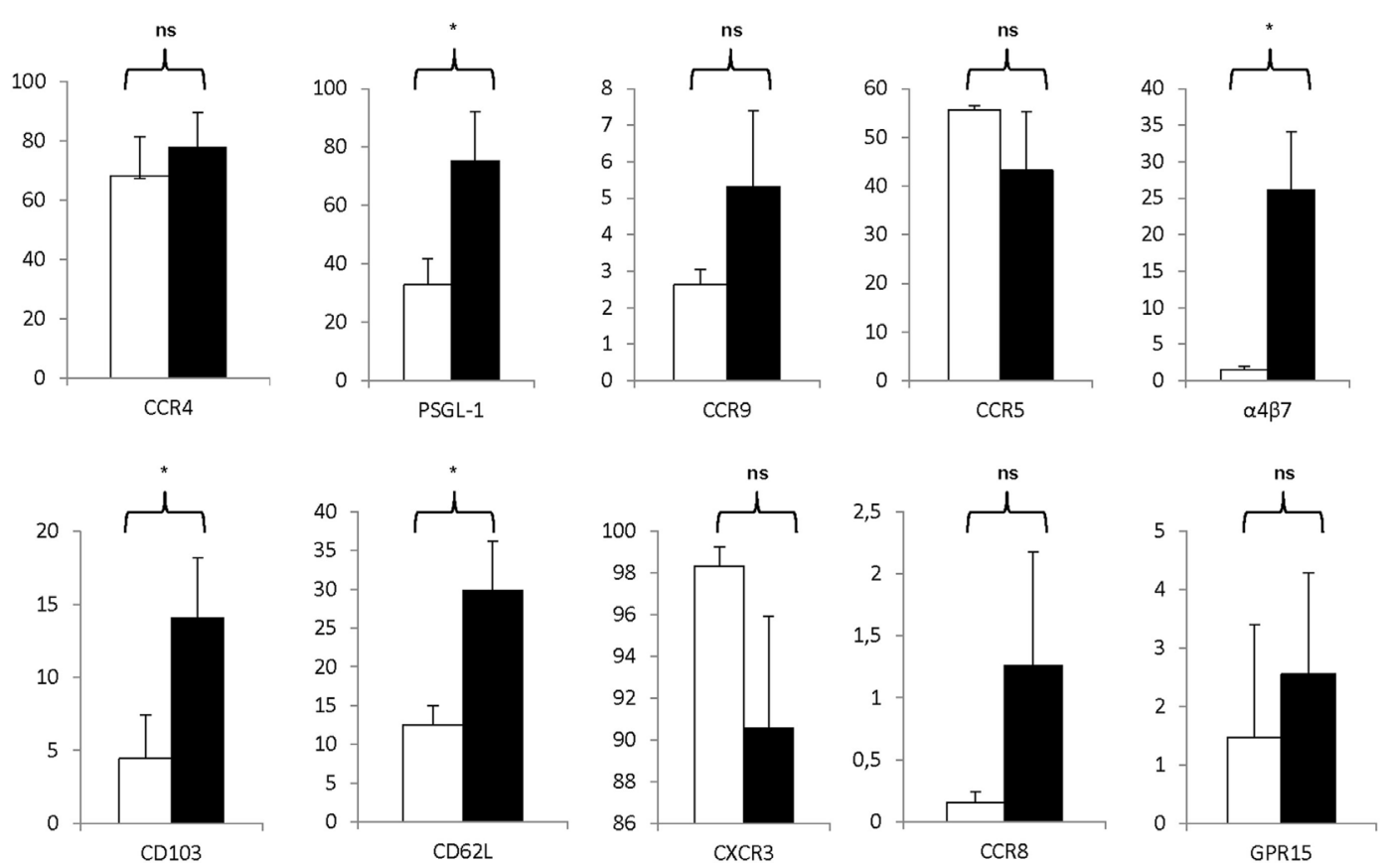

FIGURE 6 | Markers associated with homing are significantly expressed on the regulatory T cell (Treg) drug product. Proportion of CD25+ cells at day 0 (white bars) and day 21 Treg drug product cells (filled bars) expressing CCR4 $(n=4)$, PSG-1 $(n=4)$, CCR9 $(n=4), \operatorname{CCR} 5(n=4), \alpha 4 \beta 7(n=4), \operatorname{CD} 103(n=4), \operatorname{CD} 62 \mathrm{~L}(n=4)$, CXCR3 $(n=4)$, CCR8 $(n=4)$, and GPR15 $(n=4)$. NS, not significant, ${ }^{*} P<0.05$.

in the patient material or final Treg product. When the leucapherisate is tested positive for $\mathrm{HIV}, \mathrm{HBV}$, or $\mathrm{HCV}$, the production process is stopped immediately, and cell cultures will be destroyed accordingly. When the final drug product is tested positive for microbiological impurities, the product will be placed into quarantine, and is not released for clinical treatment. Confirmation tests will be performed to define if the product remains positive, and will be destroyed or was tested false positive.

Other Treg production risks include a low number of Treg after 21 days of expansion. In this case, the amount of cells regularly used for lot-release $\left(120 \times 10^{6}\right)$ could be reduced accordingly. Any out of specification result for Treg phenotype or Treg function results in the non-release of the Treg product. However, if the number of $\mathrm{CD}^{+}$cells, $\mathrm{CD} 19^{+}$cells, and/or anti-CD3/anti-CD28 expander beads exceeds the specification, the $\mathrm{CD} 8^{+} / \mathrm{CD} 19^{+}$cell depletion and/or anti-CD3/anti-CD28 expander bead removal step could be repeated. Applicable limits of detection and quantification are provided in Tables $\mathbf{1}-\mathbf{3}$, respectively.

\section{DISCUSSION}

Here, we show, for the first time, an official authority GMPapproved protocol to produce large numbers of ex vivo rapamycin-expanded $\mathrm{CD} 25^{+}$cells intended to treat inflammatory and autoimmune disorders. In addition, we provide the complete testing and validation of the lot-release of the final Treg drug product after freezing and thawing. Moreover, we extended traditional lot-release criteria and added a functional biological assay assuring the suppressive nature of the produced Treg cells at different Treg-to-effector T cell ratios. Thus far, published clinical studies testing adoptively transferred Treg included classical suppression assays as part of the immune-monitoring assays (18) after treatment of the patients to correlate clinical outcome with in vitro Treg function, but the delivered Treg product did not undergo potency testing before administration to the patient. By contrast, this Treg product is not released for clinical treatment unless in vitro suppression is proven at various cell ratios for each batch of Treg.

All the consistency runs met the specifications of the process and the product, including sterility, Treg phenotype, non-Treg cellular contamination, anti-CD3/anti-CD28 expander bead purity, and Treg function after freezing and thawing. This contrasts the general consideration that cryopreservation of Treg products is challenging (35) and that stimulation and expansion steps are necessary to restore Treg function after thawing (36).

Stability data were acquired with Treg, which were continuously stored in the gas phase of liquid nitrogen at $\leq 150^{\circ} \mathrm{C}$ for at least 12 months. Stored Treg were shown to retain Treg phenotype and function. Therefore, as advocated by Singer et al. (12), our Treg drug product could facilitate an "on demand" treatment for an acute inflammatory disease or acute allograft rejection without the time delay required for Treg enrichment and expansion. Moreover, since stability is warranted for at least 12 months, multiple Treg doses could be administered to the patient at different time points.

Besides Treg drug product stability after freezing and thawing, the Treg also remained stable after dilution in a $0.9 \%$ physiological saline infusion solution for up to $90 \mathrm{~min}$. This is an important 
assurance, since the Treg drug product will be transferred intravenously through continuous infusion using $50 \mathrm{ml}$ syringes in a perfusion pump.

Importantly, this Treg expansion protocol has several differences compared with the Treg expansion protocol intended to treat patients after liver transplantation (27). First, the presented production protocol reaches clinically relevant Treg numbers after 21 days of expansion without the need to re-stimulate the expanding Treg. Second, less than $0.1 \%$ of contaminating CD8 ${ }^{+}$ effector cells were present in the released Treg product. This is a fraction of the allowed $10 \% \mathrm{CD}^{+}$effector cells in the Treg product intended to prevent liver rejection. Third, expanded Treg remain hypomethylated at intron 1 of the FoxP3 locus, confirming their epigenetic stability. Finally, the produced Treg show suppressive function against autologous $\mathrm{CD} 8^{+}$effector cells at various Tregto-effector cell ratios; whereas the Treg produced to prevent liver rejection showed suppression of allogeneic effector cells at one Treg-to-effector cell ratio.

In the past years, several clinical studies employing expanded Treg have been conducted. The majority of studies included patients at risk for GvHD (14-16) or organ rejection $(37,38)$ after transplantation. These studies either infused ex vivo expanded Treg (14-16) or freshly isolated non-expanded Treg cells $(39,40)$. Treg infusions were well tolerated and no dose-limiting toxicities were reported $(14,15)$. In addition, the onset of both acute and chronic GvHD was favorably affected compared with historical controls and no adverse effects on non-relapse mortality or relapse were detected within a minimum follow-up of 2 years $(14,15)$. In addition, the possibility of adoptive Treg to ameliorate insulin dependency in both children and adults has been reported $(17,18)$. In these studies, Treg transfer was safe and not associated with serious adverse events in the treated children (17). By contrast, four serious adverse events were reported in the treated adults (18). Specifically, one patient experienced three episodes of serious hypoglycemia 14, 248, and 463 days after Treg treatment, and one patient experienced an episode of diabetic ketoacidosis 67 days after Treg treatment. Interestingly, by labeling with $[6,6-$ $2 \mathrm{H} 2$ ] glucose, Treg were demonstrated to persist in the peripheral circulation for up to one year after transfer (18). Finally, the safety and efficacy of ex vivo expanded ovalbumin-specific IL-10producing Treg has been assessed in patients with Crohn's disease (CD). The safety profile in this pilot study showed good tolerability and adverse events reflected the underlying CD. Moreover, a clinical significant improvement of disease symptoms was noted 5 weeks after Treg infusion in $40 \%$ of patients (41).

In conclusion, Treg produced by the presented method have broad clinical potential. Based on the fact that the presented Treg drug product is polyclonal and expressing various receptors associated with (i) lymphocyte trafficking into the skin (42,

\section{REFERENCES}

1. Vignali DA, Collison LW, Workman CJ. How regulatory T cells work. Nat Rev Immunol (2008) 8:523-32. doi:10.1038/nri2343

2. Rudensky AY. Regulatory T cells and Foxp3. Immunol Rev (2011) 241:260-8. doi:10.1111/j.1600-065X.2011.01018.x
43) (e.g., CCR4 and CD103), (ii) homing into lymphoid organs $(44,45)$ (e.g., PSGL-1 and CD62L), (iii) homing to the intestinal mucosa $(46,47)$ (e.g., CCR9 and $\alpha 4 \beta 7$ integrin), and (iv) sites of inflammation $(45,48,49)$ (e.g., PSGL-1, CD103, and CXCR3), the Treg could be effective in clinical studies aiming to treat various autoimmune-based and inflammatory disorders such as skin diseases, rheumatic diseases, intestinal inflammation, and graft-versus-host disease.

\section{ETHICS STATEMENT}

This study was carried out in accordance with the recommendations of the local Review Board (IRB) of the FriedrichAlexander Universität Erlangen-Nürnberg under IRB number 151_12B with written informed consent from all subjects. All subjects gave written informed consent in accordance with the Declaration of Helsinki. The protocol was approved by the local IRB of the Friedrich-Alexander Universität Erlangen-Nürnberg.

\section{AUTHOR CONTRIBUTIONS}

MW, DS, SR, CL, AF, IA, and CV performed experiments and analyzed data. GS and MN initiated the project. GS and BS-T acted as advisors during the GMP implementation. CV drafted the manuscript. MW, DS, SR, CL, AF, RA, CN, IA, AS, BS-T, MN, and GS critically revised the manuscript for intellectual content.

\section{ACKNOWLEDGMENTS}

The authors thank Hans-Dieter Steibl from Miltenyi Biotec, Inc. for fruitful discussion during the development of the Treg production process.

\section{FUNDING}

This work was supported by the Clinical Research Group (KFO) 257 CEDER of the German Research Council (DFG), the Medical Faculty (supporting the GMP Facility) of the Friedrich-Alexander Universität Erlangen-Nürnberg, the interdisciplinary center for clinical research (IZKF; project number J37) and the DFG Collaborative Research Centers 643 and 796 of the FriedrichAlexander Universität Erlangen-Nürnberg.

\section{SUPPLEMENTARY MATERIAL}

The Supplementary Material for this article can be found online at http://www.frontiersin.org/article/10.3389/fimmu.2017.01371/ full\#supplementary-material.
3. Liu W, Putnam AL, Xu-Yu Z, Szot GL, Lee MR, Zhu S, et al. CD127 expression inversely correlates with FoxP3 and suppressive function of human CD4+ T reg cells. J Exp Med (2006) 203:1701-11. doi:10.1084/ jem. 20060772

4. Seddiki N, Santner-Nanan B, Martinson J, Zaunders J, Sasson S, Landay A, et al. Expression of interleukin (IL)-2 and IL-7 receptors discriminates between 
human regulatory and activated T cells. JExp Med (2006) 203:1693-700. doi:10.1084/jem.20060468

5. Curotto de Lafaille MA, Lafaille JJ. Natural and adaptive foxp3+ regulatory T cells: more of the same or a division of labor? Immunity (2009) 30:626-35. doi:10.1016/j.immuni.2009.05.002

6. Horwitz DA, Zheng SG, Gray JD. Natural and TGF-beta-induced Foxp3(+) $\mathrm{CD} 4(+) \mathrm{CD} 25(+)$ regulatory $\mathrm{T}$ cells are not mirror images of each other. Trends Immunol (2008) 29:429-35. doi:10.1016/j.it.2008.06.005

7. Dieckmann D, Plottner H, Berchtold S, Berger T, Schuler G. Ex vivo isolation and characterization of $\mathrm{CD} 4(+) \mathrm{CD} 25(+) \mathrm{T}$ cells with regulatory properties from human blood. JExp Med (2001) 193:1303-10. doi:10.1084/jem. 193.11.1303

8. Jonuleit H, Schmitt E, Stassen M, Tuettenberg A, Knop J, Enk AH. Identification and functional characterization of human CD4(+)CD25(+) T cells with regulatory properties isolated from peripheral blood. J Exp Med (2001) 193:1285-94. doi:10.1084/jem.193.11.1285

9. Stephens LA, Mottet C, Mason D, Powrie F. Human CD4(+)CD25(+) thymocytes and peripheral $\mathrm{T}$ cells have immune suppressive activity in vitro. Eur J Immunol (2001) 31:1247-54. doi:10.1002/1521-4141(200104)31:4<1247:: AID-IMMU1247>3.0.CO;2-M

10. Levings MK, Sangregorio R, Roncarolo MG. Human $\operatorname{cd} 25(+) \operatorname{cd} 4(+)$ $t$ regulatory cells suppress naive and memory $\mathrm{T}$ cell proliferation and can be expanded in vitro without loss of function. J Exp Med (2001) 193:1295-302. doi:10.1084/jem.193.11.1295

11. Roncarolo MG, Battaglia M. Regulatory T-cell immunotherapy for tolerance to self antigens and alloantigens in humans. Nat Rev Immunol (2007) 7:585-98. doi:10.1038/nri2138

12. Singer BD, King LS, D’Alessio FR. Regulatory $\mathrm{T}$ cells as immunotherapy. Front Immunol (2014) 5:46. doi:10.3389/fimmu.2014.00046

13. Kmieciak M, Gowda M, Graham L, Godder K, Bear HD, Marincola FM, et al. Human T cells express CD25 and Foxp3 upon activation and exhibit effector/ memory phenotypes without any regulatory/suppressor function. J Transl Med (2009) 7:89. doi:10.1186/1479-5876-7-89

14. Brunstein CG, Miller JS, Cao Q, McKenna DH, Hippen KL, Curtsinger J, et al. Infusion of ex vivo expanded $\mathrm{T}$ regulatory cells in adults transplanted with umbilical cord blood: safety profile and detection kinetics. Blood (2011) 117:1061-70. doi:10.1182/blood-2010-07-293795

15. Brunstein CG, Miller JS, McKenna DH, Hippen KL, DeFor TE, Sumstad D, et al. Umbilical cord blood-derived T regulatory cells to prevent GVHD: kinetics, toxicity profile, and clinical effect. Blood (2016) 127:1044-51. doi:10.1182/ blood-2015-06-653667

16. Trzonkowski P, Bieniaszewska M, Juscinska J, Dobyszuk A, Krzystyniak A, Marek N, et al. First-in-man clinical results of the treatment of patients with graft versus host disease with human ex vivo expanded CD4+CD25+CD127$\mathrm{T}$ regulatory cells. Clin Immunol (2009) 133:22-6. doi:10.1016/j.clim. 2009.06.001

17. Trzonkowski P, Szarynska M, Mysliwska J, Mysliwski A. Ex vivo expansion of $\mathrm{CD} 4(+) \mathrm{CD} 25(+) \mathrm{T}$ regulatory cells for immunosuppressive therapy. Cytometry A (2009) 75:175-88. doi:10.1002/cyto.a.20659

18. Bluestone JA, Buckner JH, Fitch M, Gitelman SE, Gupta S, Hellerstein MK, et al. Type 1 diabetes immunotherapy using polyclonal regulatory $\mathrm{T}$ cells. Sci Transl Med (2015) 7:315ra189. doi:10.1126/scitranslmed.aad4134

19. Hoffmann P, Eder R, Edinger M. Polyclonal expansion of human CD4(+) CD25(+) regulatory T cells. Methods Mol Biol (2011) 677:15-30. doi:10.1007/ 978-1-60761-869-0_2

20. Marek-Trzonkowska N, Myśliwiec M, Dobyszuk A, Grabowska M, Derkowska I, Juścińska J, et al. Therapy of type 1 diabetes with CD4(+)CD25(high)CD127regulatory $\mathrm{T}$ cells prolongs survival of pancreatic islets - results of one year follow-up. Clin Immunol (2014) 153:23-30. doi:10.1016/j.clim.2014.03.016

21. Battaglia M, Stabilini A, Tresoldi E. Expanding human T regulatory cells with the mTOR-inhibitor rapamycin. Methods Mol Biol (2012) 821:279-93. doi:10.1007/978-1-61779-430-8_17

22. Coenen JJ, Koenen HJ, van RE, Hilbrands LB, Joosten I. Rapamycin, and not cyclosporin A, preserves the highly suppressive CD27+ subset of human CD4+CD25+ regulatory T cells. Blood (2006) 107:1018-23. doi:10.1182/ blood-2005-07-3032

23. Kopf H, de la Rosa GM, Howard OM, Chen X. Rapamycin inhibits differentiation of Th17 cells and promotes generation of FoxP3+ T regulatory cells. Int Immunopharmacol (2007) 7:1819-24. doi:10.1016/j.intimp.2007.08.027
24. Kahan BD, Camardo JS. Rapamycin: clinical results and future opportunities. Transplantation (2001) 72:1181-93. doi:10.1097/00007890-200110150-00001

25. Qu Y, Zhao Y. Regulatory CD4(+)CD25(+) T-cells are controlled by multiple pathways at multiple levels. Int Rev Immunol (2007) 26:145-60. doi:10.1080/08830180701365917

26. Ogino $\mathrm{H}$, Nakamura $\mathrm{K}$, Iwasa $\mathrm{T}$, Ihara $\mathrm{E}$, Akiho $\mathrm{H}$, Motomura $\mathrm{Y}$, et al. Regulatory $\mathrm{T}$ cells expanded by rapamycin in vitro suppress colitis in an experimental mouse model. J Gastroenterol (2012) 47:366-76. doi:10.1007/ s00535-011-0502-y

27. Safinia N, Vaikunthanathan T, Fraser H, Thirkell S, Lowe K, Blackmore L, et al. Successful expansion of functional and stable regulatory $\mathrm{T}$ cells for immunotherapy in liver transplantation. Oncotarget (2016) 7:7563-77. doi:10.18632/oncotarget.6927

28. Voskens CJ, Fischer A, Roessner S, Lorenz C, Hirschmann S, Atreya R, et al. Characterization and expansion of autologous GMP-ready regulatory $\mathrm{T}$ cells for TREG-based cell therapy in patients with ulcerative colitis. Inflamm Bowel Dis (2017) 23:1348-59. doi:10.1097/MIB.0000000000001192

29. Nagar M, Vernitsky H, Cohen Y, Dominissini D, Berkun Y, Rechavi G, et al. Epigenetic inheritance of DNA methylation limits activation-induced expression of FOXP3 in conventional human CD25-CD4+ T cells. Int Immunol (2008) 20:1041-55. doi:10.1093/intimm/dxn062

30. Cottrell S, Jung K, Kristiansen G, Eltze E, Semjonow A, Ittmann M, et al. Discovery and validation of 3 novel DNA methylation markers of prostate cancer prognosis. J Urol (2007) 177:1753-8. doi:10.1016/j.juro.2007.01.010

31. Baron U, Floess S, Wieczorek G, Baumann K, Grützkau A, Dong J, et al. DNA demethylation in the human FOXP3 locus discriminates regulatory $\mathrm{T}$ cells from activated FOXP3(+) conventional T cells. Eur J Immunol (2007) 37:2378-89. doi:10.1002/eji.200737594

32. Schuler-Thurner B, Schultz ES, Berger TG, Weinlich G, Ebner S, Woerl P, et al. Rapid induction of tumor-specific type $1 \mathrm{~T}$ helper cells in metastatic melanoma patients by vaccination with mature, cryopreserved, peptide-loaded monocyte-derived dendritic cells. J Exp Med (2002) 195:1279-88. doi:10.1084/ jem. 20012100

33. Thurner B, Röder C, Dieckmann D, Heuer M, Kruse M, Glaser A, et al. Generation of large numbers of fully mature and stable dendritic cells from leukapheresis products for clinical application. J Immunol Methods (1999) 223:1-15. doi:10.1016/S0022-1759(98)00208-7

34. Pillai V, Karandikar NJ. Attack on the clones? Human FOXP3 detection by PCH101, 236A/E7, 206D, and 259D reveals 259D as the outlier with lower sensitivity. Blood (2008) 111:463-4. doi:10.1182/blood-2007-09-111823

35. Golab K, Leveson-Gower D, Wang XJ, Grzanka J, Marek-Trzonkowska N, Krzystyniak A, et al. Challenges in cryopreservation of regulatory $\mathrm{T}$ cells (Tregs) for clinical therapeutic applications. Int Immunopharmacol (2013) 16:371-5. doi:10.1016/j.intimp.2013.02.001

36. Peters JH, Preijers FW, Woestenenk R, Hilbrands LB, Koenen HJ, Joosten I. Clinical grade Treg: GMP isolation, improvement of purity by CD127 depletion, Treg expansion, and Treg cryopreservation. PLoS One (2008) 3:e3161. doi:10.1371/journal.pone.0003161

37. Chandran S, Tang Q, Sarwal M, Laszik ZG, Putnam AL, Lee K, et al. Polyclonal regulatory $\mathrm{T}$ cell therapy for control of inflammation in kidney transplants. Am J Transplant (2017). doi:10.1111/ajt.14415

38. Todo S, Yamashita K, Goto R, Zaitsu M, Nagatsu A, Oura T, et al. A pilot study of operational tolerance with a regulatory T-cell-based cell therapy in living donor liver transplantation. Hepatology (2016) 64:632-43. doi:10.1002/ hep. 28459

39. Di Ianni M, Falzetti F, Carotti A, Terenzi A, Castellino F, Bonifacio E, et al. Tregs prevent GVHD and promote immune reconstitution in HLAhaploidentical transplantation. Blood (2011) 117:3921-8. doi:10.1182/blood2010-10-311894

40. Martelli MF, Di Ianni M, Ruggeri L, Falzetti F, Carotti A, Terenzi A, et al. HLA-haploidentical transplantation with regulatory and conventional T-cell adoptive immunotherapy prevents acute leukemia relapse. Blood (2014) 124:638-44. doi:10.1182/blood-2014-03-564401

41. Desreumaux P, Foussat A, Allez M, Beaugerie L, Hébuterne X, Bouhnik Y, et al. Safety and efficacy of antigen-specific regulatory T-cell therapy for patients with refractory Crohn's disease. Gastroenterology (2012) 143:1207-17. doi:10.1053/j.gastro.2012.07.116

42. Campbell JJ, O'Connell DJ, Wurbel MA. Cutting edge: chemokine receptor CCR4 is necessary for antigen-driven cutaneous accumulation of CD4 T cells 
under physiological conditions. J Immunol (2007) 178:3358-62. doi:10.4049/ jimmunol.178.6.3358

43. Sather BD, Treuting P, Perdue N, Miazgowicz M, Fontenot JD, Rudensky AY, et al. Altering the distribution of Foxp3(+) regulatory $\mathrm{T}$ cells results in tissue-specific inflammatory disease. JExp Med (2007) 204:1335-47. doi:10.1084/jem.20070081

44. Florek M, Schneidawind D, Pierini A, Baker J, Armstrong R, Pan Y, et al. Freeze and thaw of CD4+CD25+Foxp3+ regulatory $\mathrm{T}$ cells results in loss of CD62L expression and a reduced capacity to protect against graft-versus-host disease. PLoS One (2015) 10:e0145763. doi:10.1371/journal.pone.0145763

45. Veerman KM, Williams MJ, Uchimura K, Singer MS, Merzaban JS, Naus S, et al. Interaction of the selectin ligand PSGL-1 with chemokines CCL21 and CCL19 facilitates efficient homing of $\mathrm{T}$ cells to secondary lymphoid organs. Nat Immunol (2007) 8:532-9. doi:10.1038/ni1456

46. De Calisto J, Villablanca EJ, Wang S, Bono MR, Rosemblatt M, Mora JR. T-cell homing to the gut mucosa: general concepts and methodological considerations. Methods Mol Biol (2012) 757:411-34. doi:10.1007/978-161779-166-6_24

47. Fischer A, Zundler S, Atreya R, Rath T, Voskens C, Hirschmann S, et al. Differential effects of alpha4beta7 and GPR15 on homing of effector and regulatory T cells from patients with UC to the inflamed gut in vivo. Gut (2016) 65(10):1642-64. doi:10.1136/gutjnl-2015-310022

48. Mackay CR. CXCR3(+)CCR5(+) T cells and autoimmune diseases: guilty as charged? J Clin Invest (2014) 124:3682-4. doi:10.1172/JCI77837

49. Tomura M, Honda T, Tanizaki H, Otsuka A, Egawa G, Tokura Y, et al. Activated regulatory $\mathrm{T}$ cells are the major $\mathrm{T}$ cell type emigrating from the skin during a cutaneous immune response in mice. JClin Invest (2010) 120:883-93. doi:10.1172/JCI40926

Conflict of Interest Statement: The authors declare that the research was conducted in the absence of any commercial or financial relationships that could be construed as a potential conflict of interest.

Copyright (c) 2017 Wiesinger, Stoica, Roessner, Lorenz, Fischer, Atreya, Neufert, Atreya, Scheffold, Schuler-Thurner, Neurath, Schuler and Voskens. This is an openaccess article distributed under the terms of the Creative Commons Attribution License (CC BY). The use, distribution or reproduction in other forums is permitted, provided the original author(s) or licensor are credited and that the original publication in this journal is cited, in accordance with accepted academic practice. No use, distribution or reproduction is permitted which does not comply with these terms. 